\title{
Is There a Role for Basophils in Cancer?
}

OPEN ACCESS

Edited by:

Fabio Malavasi,

University of Turin, Italy

Reviewed by:

Alessandro Poggi,

San Martino Hospital (IRCCS), Italy

Arya Biragyn,

National Institutes of Health $(\mathrm{N} / \mathrm{H})$,

United States

Kia Joo Puan,

Singapore Immunology Network

(A*STAR), Singapore

*Correspondence:

Gilda Varricchi

gildanet@gmail.com

tThese authors share senior authorship

¥ORCID:

Giancarlo Marone

orcid.org/0000-0003-0233-7830

John T. Schroeder

orcid.org/0000-0002-5263-7850

Fabrizio Mattei

orcid.org/0000-0002-5357-7773

Stefania Loffredo

orcid.org/0000-0002-5871-1898

Adriana Rosa Gambardella

orcid.org/0000-0002-5335-8650

Remo Poto

orcid.org/0000-0002-4723-0167

Amato de Paulis

orcid.org/0000-0003-0347-2540

Giovanna Schiavoni

orcid.org/0000-0001-9135-0556

Gilda Varricch

orcid.org/0000-0002-9285-4657

Specialty section:

This article was submitted to

Cancer Immunity and Immunotherapy,

a section of the journal

Frontiers in Immunology

Received: 13 May 2020

Accepted: 03 August 2020

Published: 08 September 2020

\author{
Giancarlo Marone ${ }^{1,2 \ddagger}$, John T. Schroeder ${ }^{3 \ddagger}$, Fabrizio Mattei ${ }^{4 \ddagger}$, Stefania Loffredo $5,6,7,8 \neq$, \\ Adriana Rosa Gambardella ${ }^{4 \neq}$, Remo Poto ${ }^{5,6 \neq}$, Amato de Paulis ${ }^{5,6,7 \neq}$, Giovanna Schiavoni ${ }^{4 \neq}$ \\ and Gilda Varricchi ${ }^{5,6,7,8 * t \neq}$ \\ ${ }^{1}$ Section of Hygiene, Department of Public Health, University of Naples Federico II, Naples, Italy, ${ }^{2}$ Azienda Ospedaliera \\ Ospedali dei Colli, Monaldi Hospital Pharmacy, Naples, Italy, ${ }^{3}$ Division of Allergy and Clinical Immunology, Department of \\ Medicine, Johns Hopkins Asthma and Allergy Center, Johns Hopkins University, Baltimore, MD, United States, ${ }^{4}$ Department \\ of Oncology and Molecular Medicine, Istituto Superiore di Sanità, Rome, Italy, ${ }^{5}$ Department of Translational Medical \\ Sciences, University of Naples Federico II, Naples, Italy, ${ }^{6}$ Center for Basic and Clinical Immunology Research (CISI), \\ University of Naples Federico II, Naples, Italy, ${ }^{7}$ WAO Center of Excellence, Naples, Italy, ${ }^{8}$ Institute of Experimental \\ Endocrinology and Oncology "G. Salvatore", National Research Council (CNR), Naples, Italy
}

Basophils were identified in human peripheral blood by Paul Ehrlich over 140 years ago. Human basophils represent $<1 \%$ of peripheral blood leukocytes. During the last decades, basophils have been described also in mice, guinea pigs, rabbits, and monkeys. There are many similarities, but also several immunological differences between human and mouse basophils. There are currently several strains of mice with profound constitutive or inducible basophil deficiency useful to prove that these cells have specific roles in vivo. However, none of these mice are solely and completely devoid of all basophils. Therefore, the relevance of these findings to humans remains to be established. It has been known for some time that basophils have the propensity to migrate into the site of inflammation. Recent observations indicate that tissue resident basophils contribute to lung development and locally promote M2 polarization of macrophages. Moreover, there is increasing evidence that lung-resident basophils exhibit a specific phenotype, different from circulating basophils. Activated human and mouse basophils synthesize restricted and distinct profiles of cytokines. Human basophils produce several canonical (e.g., VEGFs, angiopoietin 1) and non-canonical (i.e., cysteinyl leukotriene $\mathrm{C}_{4}$ ) angiogenic factors. Activated human and mouse basophils release extracellular DNA traps that may have multiple effects in cancer. Hyperresponsiveness of basophils has been demonstrated in patients with $\mathrm{JAK} 2^{\mathrm{V} 617 \mathrm{~F}}$-positive polycythemia vera. Basophils are present in the immune landscape of human lung adenocarcinoma and pancreatic cancer and can promote inflammation-driven skin tumor growth. The few studies conducted thus far using different models of basophil-deficient mice have provided informative results on the roles of these cells in tumorigenesis. Much more remains to be discovered before we unravel the hitherto mysterious roles of basophils in human and experimental cancers.

Keywords: angiogenesis, angiopoietins, basophil, cancer, cysteinyl leukotrienes, cytokines, vascular endothelial growth factors 


\section{INTRODUCTION}

Peripheral blood basophils and tissue mast cells were described over 140 years ago by Paul Ehrlich the founder of modern Immunology $(1,2)$. Basophils have been characterized in humans (3), guinea pigs (4), mice $(5,6)$, rabbits (7) and monkeys (8). Basophils represent $<1 \%$ of human peripheral leukocytes, whereas mast cells are ubiquitous in essentially all tissues $(9,10)$. Basophils share some characteristics with mast cells, including the presence of similar, but distinctive basophilic granules within the cytoplasm (11), surface expression of the full tetramer $\left(\alpha \beta \gamma_{2}\right)$ form of the high affinity receptor for $\operatorname{IgE}(\mathrm{Fc \varepsilon RI})$ and release of proinflammatory mediators such as histamine and cysteinyl leukotrienes $(12,13)$. These similarities had initially generated the erroneous hypothesis that basophils represented the circulating precursor/counterpart of tissue mast cells. This concept is no longer accepted, as there is now ample evidence that human basophils and mast cells differ morphologically, ultrastructurally, immunologically, biochemically, and pharmacologically (1315). In a series of eloquent studies, Ann M. Dvorak carefully described and compared the distinctive morphological and ultrastructural features of human basophils and mast cells (11). Figure 1 illustrates the striking ultrastructural differences between human peripheral blood basophils and lung mast cells (18). In addition to highlighting key ultrastructural differences between basophils and mast cells, Dr. Dvorak also pioneered the characterization of mouse basophils. In fact, there was early belief that questioned the existence of basophils in mice. However, Dr. Dvorak's meticulous work clearly identified mouse basophils as a rare, and often elusive, population of granular cells typically found in bone marrow, with some ultrastructural characteristics similar to human basophils $(6,11$, 19).

\section{BASOPHIL DEVELOPMENT}

Like other myeloid lineages basophils develop from hematopoietic stem cells in the bone marrow (20). IL-3 is generally viewed as the most important growth factor for basophil development, both in humans and mice (21, 22). Indeed, human and murine basophils can be generated in vitro by culturing bone marrow cells in the presence of recombinant IL-3 (23-25). More recently, it has been proposed that thymic stromal lymphopoietin (TSLP) is another growth factor important for the development of mouse basophils (26). Interestingly, IL-3- and TSLP-elicited murine basophils differ in terms of gene expression and functions, suggesting heterogeneity among these basophil populations (27). A study has suggested clinical relevance to this concept in reporting evidence that a small percentage (? 10\%) of basophils isolated from asthmatic patients express the TSLP receptor and respond directly to TSLP by releasing histamine and cytokines (28). In contrast, subsequent studies have failed to confirm these findings, showing that human basophils lack expression of the IL-7R $\alpha$ subunit of TSLP receptor (29) and are unresponsive to in vitro stimulation with $\operatorname{TSLP}(29,30)$. Collectively, these findings illustrate some of the controversies yet to be resolved between human and mouse basophils, but also those within each species $(13,31,32)$.
A

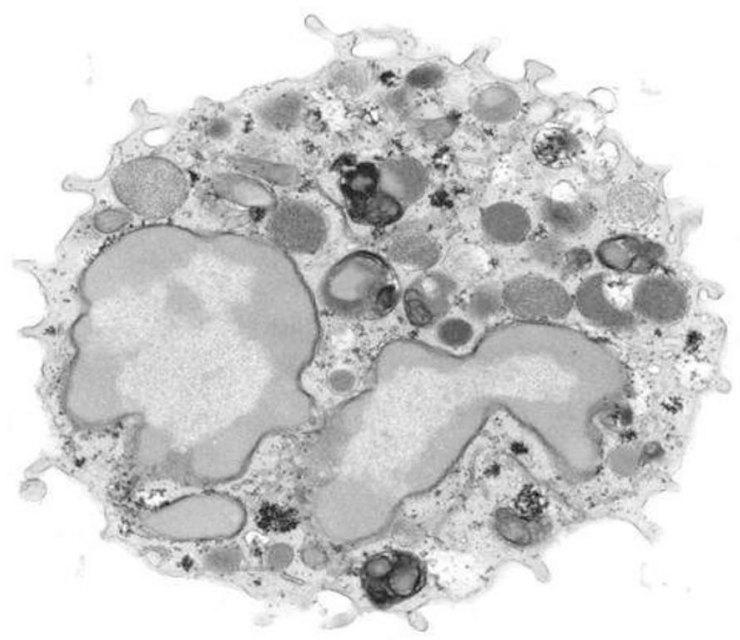

B

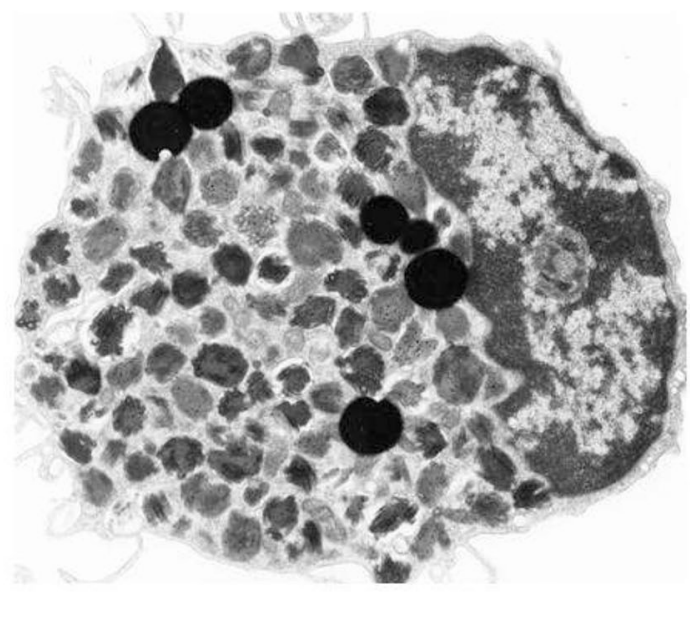

FIGURE 1 | Morphologic and ultrastructural differences between human basophils and mast cells. (A) Human peripheral blood basophil shows irregular blunt surface processes and a polylobed nucleus with condensed chromatin pattern. The cytoplasm contains large-membrane bound secretory granules filled with electron dense particles and/or finely granular material (11) X 21,500. (B) Isolated human lung mast cell has a narrow surface fold and single lobed nucleus with partially condensed chromatin pattern. The cytoplasm is filled with a large number of membrane-bound secretory granules that have an extremely variable ultrastructural pattern (16, 17). The cytoplasm also contains six non-membrane-bound spherical lipid bodies that are larger than secretory granules, are osmophilic and do not contain scrolls $(16,17) \times 14,000$. Photos kindly provided by Ann M. Dvorak and reproduced with permission from Marone et al. (18). 


\section{PROINFLAMMATORY AND IMMUNOREGULATORY MEDIATORS/CYTOKINES RELEASED BY BASOPHILS: HUMAN VS. MOUSE}

Many phenotypic markers have been identified on human and mouse basophils, with some minor differences worth noting. For example, basophils from both species express of a variety of activation-linked markers, namely FceRI $(33,34)$, but also the degranulation marker, CD63 (35-37), as well as CD203c an ecto-nucleotide pyrophosphatase/phosphodiesterase (15, 36, $38,39)$. In contrast, human basophils express the IgG receptors Fc $\gamma$ RIIA, Fc $\gamma$ RIIB, and minute amounts of Fc $\gamma$ RIIIB, whereas mouse basophils express Fc $\gamma$ RIIB and Fc $\gamma$ RIIIA $(40,41)$. As indicated above, both human and mouse basophils express receptors for IL-3 (CD123) (26, 42), but also for GM-CSF (CD116) (43), and IL-33 (ST2) (44-47). Again, it remains unclear whether they similarly express the heterodimeric receptor for TSLP (26, 28-30). To date, only human basophils are reported to express IL-5 receptors (CD125). Human basophils express tropomyosin receptor kinase A (TrkA) $(48,49)$-the high affinity receptor for nerve growth factor (NGF) and that this factor mediates functional activity (50). In contrast, there are currently no reports that mouse basophils express TrkA. Both human and mouse basophils share the expression of a variety of chemokine receptors $(13,51-56)$, but it remains to be determined if mouse basophils express CCR1 and CXCR1 (57). These phenotypic comparisons between human and mouse basophils are summarized in Table $\mathbf{1 .}$

There are several proinflammatory mediators found preformed in human basophils, including histamine $(\simeq 1$ $\mathrm{pg} /$ cell), basogranulin $(57,77)$ and very low concentrations of tryptase (78). Human (79) and mouse basophils release granzyme B (80), which possesses cytotoxic effects on cancer cells $(81,82)$. Both human and mouse basophils rapidly synthesize cysteinyl leukotriene $\mathrm{C}_{4}\left(\mathrm{LTC}_{4}\right)$ through the 5-lipoxygenase pathway (83). There is evidence that mouse basophils metabolize arachidonic acid through cyclooxygenase activity to form prostaglandin $\mathrm{D}_{2}\left(\mathrm{PGD}_{2}\right)$ and prostaglandin $\mathrm{E}_{2}\left(\mathrm{PGE}_{2}\right)(72,84)$. In contrast, there is currently no solid evidence that highly purified human basophils can produce measurable levels of $\mathrm{PGD}_{2}$, or any other lipid mediator generated through the cyclooxygenase pathway (85).

With regard to the cytokines secreted by human $v s$. mouse basophils, there are several similarities and differences. First, it is now well-accepted that both human and mouse basophils produce IL-4 (44, 86-97) and IL-13 (44, 89, 92, 94, 97100). Several reports show that mouse basophils additionally produce IL- $6(44,73,101)$ and TNF- $\alpha(44,73)$. There are at least two publications reporting TNF-? production by human basophils $(88,102)$. Numerous attempts to detect this cytokine in supernatants of highly purified human basophils activated by IgE-mediated stimuli have produced negative results. Certainly, other cell types (e.g., monocytes, DCs) produce copious amounts of TNF-? and IL-6 $(103,104)$, thus making it possible that even low-level contamination with these cells could skew the basophil
TABLE 1 | Comparison of the phenotypic differences between human and mouse basophils ${ }^{a, b}$.

\begin{tabular}{|c|c|c|c|}
\hline Phenotypic Marker & $\begin{array}{l}\text { Human } \\
\text { Basophil }\end{array}$ & $\begin{array}{l}\text { Mouse } \\
\text { Basophil }\end{array}$ & References \\
\hline $\mathrm{F}_{\mathrm{C} \varepsilon \mathrm{Rl}}$ & ++ & ++ & (34) \\
\hline$F_{C} \gamma R \| A$ & + & - & $(33,40,58)$ \\
\hline$F_{c} \gamma R \| B$ & + & + & $(33,40,58)$ \\
\hline Fc $\gamma R \| I I A$ & - & + & $(33,40,58,59)$ \\
\hline Fc $\gamma R \| I B$ & \pm & - & $(33,40,58,60)$ \\
\hline CD63 & + & + & $(35-37)$ \\
\hline CD203c & + & + & $(15,36,38,39)$ \\
\hline (CD123) IL-3R $\alpha$ & ++ & ++ & $(26,42)$ \\
\hline (CD116) GM-CSFR $\alpha$ & + & + & (43) \\
\hline (CD125) IL-5R $\alpha$ & + & ND & $(43)$ \\
\hline TSLPR & - & + & $(26,28-30,32)$ \\
\hline (ST2) IL-33R & + & + & $(44-47)$ \\
\hline CCR1 & + & ND & $(13,51)$ \\
\hline CCR2 & ++ & + & $(13,51-53)$ \\
\hline CCR3 & ++ & \pm & $(13,51,61)$ \\
\hline CCR5 & + & - & $(13,51,53)$ \\
\hline CXCR1 & ++ & ND & $(13,51)$ \\
\hline CXCR2 & + & + & $(13,51,62)$ \\
\hline CXCR4 & + & + & $(13,51,62,63)$ \\
\hline CRTH2 & ++ & + & $(51,55,62,64,65)$ \\
\hline CD200R & + & + & $(56,66)$ \\
\hline CD300a & + & + & $(67-69)$ \\
\hline CD300c & + & + & $(68,70)$ \\
\hline CD300f & + & + & $(68,70)$ \\
\hline PD-L1 & + & ND & (50) \\
\hline VEGFR2 & + & ND & (57) \\
\hline NRP1/2 & + & ND & (57) \\
\hline TrKA & + & ND & $(48,49)$ \\
\hline
\end{tabular}

ND, not done.

a Several key surface markers are used to characterize human $\left[\mathrm{lgE}{ }^{+}, \mathrm{FC} C \mathrm{R} \mathrm{I}^{+}, \mathrm{CCR}^{+}\right.$,

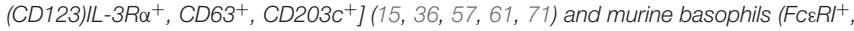

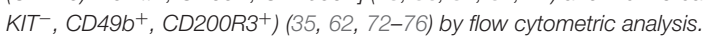

${ }^{b}$ This table essentially includes the phenotypic characteristics of peripheral blood human and mouse basophils. Phenotypic and/or molecular characteristics of human (50) and mouse basophils in tissues $(26,39,44,53,55,62)$ are also included.

+: means "expressed"; ++: means "highly expressed"; - means "not expressed"; \pm : means "probably expressed under certain circumstances".

findings. This issue must be taken into consideration each time any cytokine is reportedly made by basophils. Nevertheless, consistent with the general theme of this review, it is becoming apparent that basophils secrete several angiogenic factors that, when combined with the cytokines thus far mentioned, point to a possible role for these cells in wound healing and/or tumorigenesis (as further discussed below). In particular, vascular endothelial growth factor-A (VEGF-A) (57), angiopoietin-1 (ANGPT1) (105), hepatocyte growth factor (HGF) $(44,106)$, and amphiregulin $(71,107,108)$ are all reportedly produced by human basophils, with some of these also made by 
TABLE 2 | Comparison of the mediators differently produced by human and mouse basophils.

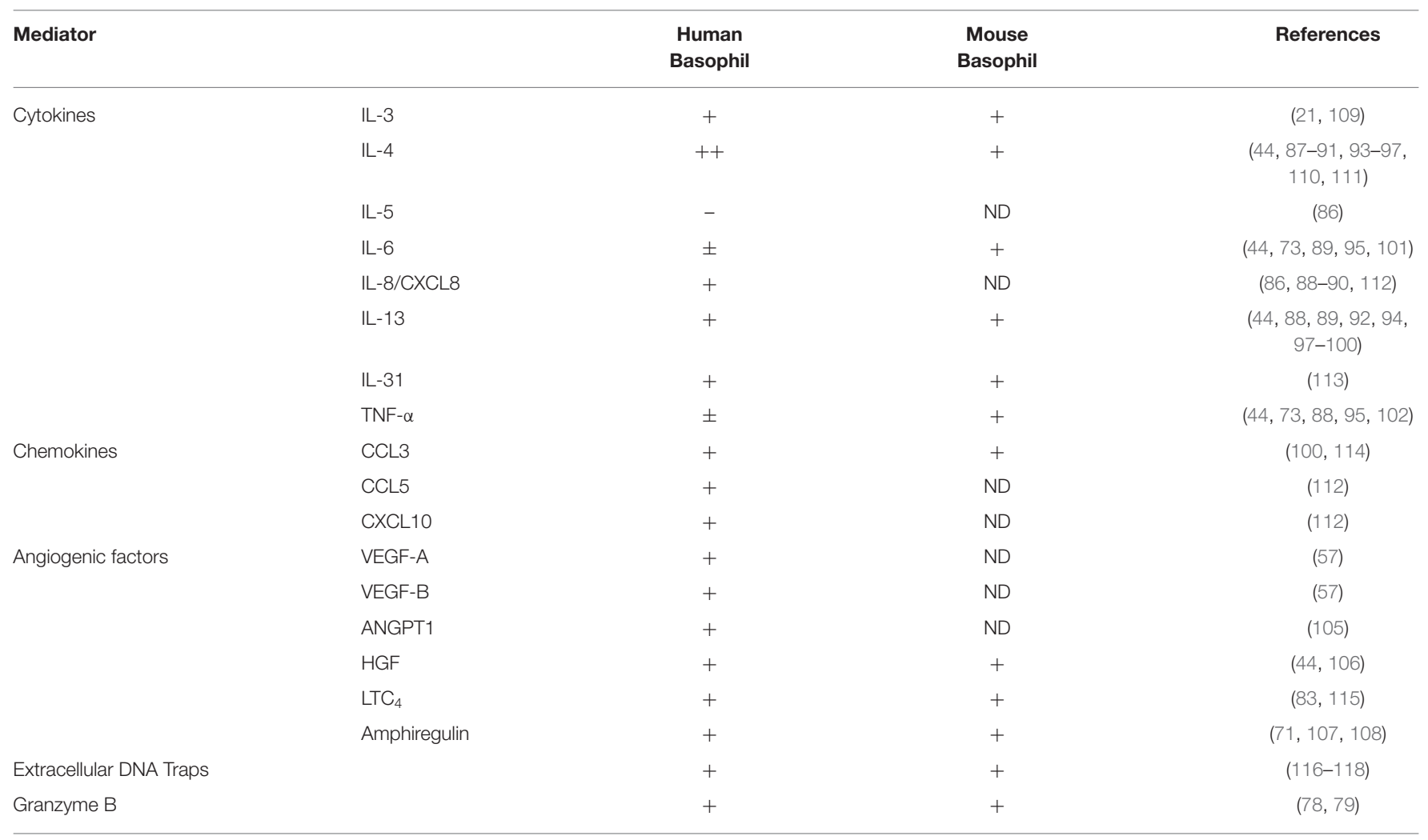

ND, not done.

+: means "expressed"; ++: means "highly expressed"; - means "not expressed"; \pm : means "probably poorly expressed".

mouse basophils (44). Table 2 summarizes the cytokines/factors produced by human $v$ s. mouse basophils.

There are many other fundamentals of basophil biology not discussed herein, but have been extensively reviewed elsewhere $(13,86,119-123)$. In this review, we focus our discussion instead on the relatively novel concept of how basophils and their mediators/cytokines may play a role in promoting or limiting tumorigenesis.

\section{DIFFERENCES BETWEEN PERIPHERAL BLOOD AND TISSUE BASOPHILS}

The life-span of peripheral blood basophils has been calculated to be relatively short (? 2.5 days in mice) (124) and therefore newly generated basophils are constantly supplied from the bone marrow to the blood (20). It has long been thought that basophils circulate in peripheral blood and are rarely present in tissues unless during specific kinds of inflammation, reported both in mice $(62,73,124-126)$ and in humans $(50,127-131)$. However, this dogma has been recently challenged by a study in mice whereby the authors found that basophils are present in all phases of lung development (44). Lung-resident basophils localize in close proximity of alveoli and, interestingly, exhibit a specific phenotype, highly divergent from peripheral blood basophils.
IL-33 and GM-CSF produced in the pulmonary environment mediate the specific gene signature of lung alveolar basophils. Importantly, lung basophils are essential for transcriptional and functional development of alveolar macrophages and their polarization toward the M2 state. The latter finding raises the intriguing possibility that in pathologies characterized by M2 macrophages, as happens in many tumors $(132,133)$, basophils may be involved in regulating the activity of tumor-associated macrophages. This experimental study has several relevant pathophysiological implications. First, it demonstrates that tissue resident basophils exhibit a specific phenotype, different from circulating basophils. Second, the tissue microenvironment can modulate the specific gene signature of resident basophils through exposure to cytokines (e.g., IL-33, GM-CSF). Third, lung resident basophils can influence the transcriptional and functional development of macrophages. The observations of this elegant study represent important premises for future research.

We would like to suggest that any difference between circulating and tissue basophils should be confirmed in human models, given the differences between human and murine basophils. Moreover, studies are urgently needed to characterize the possible roles of tissue basophils residing in the tumor microenvironment (TME) of different human tumors in order to identify novel potential prognostic biomarkers and therapeutic targets. 


\section{CANONICAL AND NON-CANONICAL ANGIOGENIC FACTORS PRODUCED BY BASOPHILS}

Angiogenesis, the formation of new blood vessels from preexisting ones via a process called sprouting, represents one of the hallmarks of cancer $(134,135)$. Angiogenesis is a highly complex process that may occur under physiological conditions, such as during embryonic development. Pathological angiogenesis can occur in inflammation and in cancer and is driven by the coordinated overexpression of several proangiogenic factors (136). Unlike wound healing, where angiogenesis undergoes a resolution phase, tumor angiogenesis continues abnormally in growing cancers supported by angiogenic factors produced by both cancer cells and infiltrated immune cells $(137,138)$. The VEGF family (VEGF-A, VEGF-B, VEGF-C, VEGF-D) and their receptors (VEGFR1, VEGFR2, VEGFR3) play intricate roles in initiating and promoting tumor and inflammatory angiogenesis (136). Activated human basophils release substantial amounts of VEGF-A, the most potent proangiogenic molecule (57). VEGFs are potent chemotactic stimuli for human basophils through the engagement of VEGFR2expressed in these cells $(57,139)$. Thus, VEGFs produced by tumor cells and by several immune cells in TME $(136,139-141)$ can induce basophil chemotaxis through the activation of VEGFR2 on their surface.

The angiopoietin/Tie receptor system is another player in tumor angiogenesis. Angiopoietins (ANGPTs) are a group of growth factors that are involved in regulating vascular functions (142). ANGPTs and their receptors (Tie1 and Tie2) participate in inflammatory and tumor angiogenesis (143). ANGPT1 binds with high affinity to the Tie2 receptor on endothelial cells and promotes endothelial stabilization (144). By contrast, ANGPT2, released by activated endothelial cells, causes vascular permeability. Human basophils constitutively express ANGPT1 and ANGPT2 mRNAs (105). In vitro basophil activation causes the release of ANGPT1. Hepatocyte growth factor (HGF) is one of the most powerful angiogenic factors (145) and human basophils are a major source of HGF (106). Recently, it has been demonstrated that mouse lung-resident basophils express a specific gene signature including $\mathrm{Hgf}$ (44).

The cysteinyl leukotrienes (cys-LTs) are lipid mediators initially characterized for their proinflammatory activities (146). The cys-LTs include leukotriene $\mathrm{C}_{4}\left(\mathrm{LTC}_{4}\right), \mathrm{LTD}_{4}$, and $\mathrm{LTE}_{4}$. $\mathrm{LTC}_{4}$ is de novo synthesized by several immune cells (146, $147)$ and is the major lipid mediator produced by activated human basophils $(83,115)$. LTC $_{4}$ is converted by the extracellular enzymes, $\gamma$-glutamyl transpeptidases to $\mathrm{LTD}_{4}$ and to $\mathrm{LTE}_{4}$ by the membrane-bound dipeptidases (146). Cys-LTs activate three distinct receptors (CysLTRs) CysLT ${ }_{1} R, C_{\text {Cyst }} R$, and $\mathrm{CysLT}_{3} \mathrm{R}$ (148-150). Recent evidence demonstrates that $\mathrm{LTC}_{4}$ and $\mathrm{LTD}_{4}$ were equipotent in forming tubes in the Matrigel in vitro assay of angiogenesis (151). The proangiogenic activities of $\mathrm{LTC}_{4}$ and $\mathrm{LTD}_{4}$ were also confirmed in vivo and were found to be mediated by the engagement of $\mathrm{CysLT}_{2} \mathrm{R}$ on blood endothelial cells (BECs). CysLT 2 R deficiency and pharmacologic antagonism reduced tumor growth and the formation of lung metastases in a mouse model of Lewis lung carcinoma (151). These novel findings emphasize the importance of cys-LTs as non-canonical angiogenic factors in cancer. It is possible to speculate that $\mathrm{LTC}_{4}$ released by circulating basophils can activate CysLT $_{2} \mathrm{R}$ overexpressed in tumor BECs (151), thus contributing to angiogenesis. It has been suggested that $\mathrm{CysLT}_{2} \mathrm{R}$ might represent a possible pharmacologic target in tumor growth and metastases formation (151).

\section{FORMATION OF EXTRACELLULAR DNA TRAPS BY BASOPHILS}

Extracellular traps (ETs) are DNA structures released by activated immune cells, including neutrophils, eosinophils, mast cells, macrophages, and basophils $(116,117,152-155)$. ETs released by these cells are draped with proteins from primary granules (e.g., myeloperoxidase and elastase) (156), secondary granules (e.g., lactoferrin and pentraxin 3) $(156,157)$, and tertiary granules (e.g., matrix metalloproteinase 9) (156). Initial studies highlighted the antibacterial activity of ETs $(154,158,159)$. During the last years, there has been increasing evidence that ETs, particularly neutrophil extracellular traps (NETs), have a role in different aspects of cancer (160). For instance, it has been demonstrated that NETs can promote cancer metastasis in mouse models and in humans (161-164). Moreover, it has been found that NETs formed during lung inflammation awaken dormant cancer cells (165). Neutrophils from patients with myeloproliferative neoplasms associated with JAK2 ${ }^{\mathrm{V} 617 \mathrm{~F}}$ somatic mutation have an increase in NET formation and thrombosis and mice with knock-in of $J A K 2^{\mathrm{V} 617 \mathrm{~F}}$ have an increased propensity for NET formation and thrombosis (166). Recently, we have demonstrated that anaplastic thyroid cancer cells can induce the release of mitochondrial DNA traps by viable neutrophils (167). Collectively, these studies indicate that NETs can sustain several aspects of tumor growth, the formation of metastasis, and promote cancer-associated thrombosis. Activated human and mouse basophils can form extracellular DNA traps (BETs) in vitro and in vivo (116-118). Future studies should investigate whether BETs modulate tumor growth and the formation of metastasis in preclinical models and/or in human cancer.

\section{BASOPHIL-DEPLETED MICE TO INVESTIGATE BASOPHIL FUNCTIONS IN VIVO}

It seems pertinent to review the mouse models currently employed to investigate basophil functions in vivo. Basophildepleted mice will certainly play a critical role in discerning the functions of this granulocyte in cancer. Indeed, several models of basophil-deficient mice have been developed and are undergoing testing for this very purpose.

Initially, studies were performed using administration of antibodies that transiently deplete basophils. These antibodies recognize either the FceRI (MAR-1) (168) or the activating 
receptor CD200R3 (Ba103) (169). Although these antibodies can deplete basophils, they can also deplete/activate other cells (e.g., mast cells, DCs, monocytes) expressing FceRI (169171). Furthermore, Ba103 is FcR-dependent and might activate myeloid cells and NK cells (168). Studies using these depleting antibodies have led to the controversial conclusion that basophils have a role as antigen-presenting cells (APCs) during Th2 polarization $(95,172,173)$. Several new mouse strains with constitutive or inducible depletion of basophils have recently been generated (119). The Bas-TRECK and the $M c p t 8^{\mathrm{DTR}}$ are two diphtheria toxins (DT)-inducible basophil depletion mice models $(125,174)$. The latter models are characterized by a transient depletion of more than $90 \%$ of basophils. The $M c p t 8^{\mathrm{DTR}}$ mice express the human diphtheria toxin (DT) receptor (DTR), which makes it possible to induce a transient ( $\sim 5$ days) depletion of basophils after intraperitoneal treatment with DT (125). The Mcpt8 gene is specifically expressed by basophils $(175,176)$ and encodes mouse mast cell protease 8 (mMCP-8), a granzyme Blike protease stored in the secretory granules of basophils (175). Although the expression of Mcpt8 is specific to basophils among mature cells, it is still transiently expressed at the progenitor stage to a sufficient level to allow their depletion by a high dose of $\mathrm{DT}$ in the $M c p t 8^{\mathrm{DTR}}$ mice (177). Injection of DT in Bas-TRECK mice also causes efficient $(\geq 90 \%)$ depletion of basophils (174). In this model, the human DTR was inserted under control of the 3' proximal enhancer in the IL4 locus.

Basoph8 (Mcpt $\left.8^{\mathrm{IRES}-\mathrm{YP}-\mathrm{Cre}}\right)$ (178), Mcpt8-Cre (179) and P1-Runx1 (180) are three different mouse models showing constitutive depletion ( $90 \%)$ of basophils. The Mcpt8-Cre model was developed by engineering a bacterial artificial chromosome transgenic mouse that expresses the Cre recombinase under control of the regulatory elements of Mcpt8 (179). Mcpt8-Cre mice are constitutively deficient for basophils; therefore, this model is suitable for experiments that need long-term ablation of these cells. In the Basoph8 $\left(M c p t 8^{\text {IRES-YP-Cre }}\right)$ mice an IRES-YFP-Cre cassette was inserted before the start codon of the Mcpt8 gene (178). The dysruption of the distal (P1) promoter of the transcription factor Runx1 resulted in $>90 \%$ depletion of basophils indicating that Runx1 plays a critical role in the development of mouse basophils (180). Runx $1^{\text {PIN/P1N }}$ mice have markedly reduced numbers of basophils in bone marrow, spleen and peripheral blood (180). Recently, a new mouse model $\left(M c p t 8^{\mathrm{iCre} /+} I 4^{\mathrm{fl} / \mathrm{fl}}\right)$ was established by crossing two mouse stains, Mcpt $8^{\mathrm{iCre} /+}$ and $I l 4^{\mathrm{fl} / \mathrm{fl}}$ mice (74). These mice are selectively deficient for IL-4 only in basophils and are thus suitable to assess the role of basophil-derived IL-4 in different pathophysiological conditions, including cancer. Several excellent reviews have analyzed in details the different mouse models to investigate basophil functions in vivo $(75,119,181,182)$.

It is important to emphasize that previous studies using antibody-depleted basophils (114) and genetically engineered models $(62,91)$ provided contrasting results on the role of basophils in cancer. Moreover, it should be pointed out that even new mouse mutants have some hematological abnormalities (177). Therefore, results obtained with basophil-deficient mouse models should be interpreted with caution.

\section{PERIPHERAL BLOOD BASOPHILS AND HUMAN CANCER}

It has been well-known for some time that basophilia can occur during the advanced phase of chronic myeloid leukemia (CML) (183). The transcription factor IKAROS is markedly reduced in bone marrow from CML patients (184). Overexpression of the dominant-negative isoform of IKAROS in $\mathrm{CD}_{3} 4^{+}$cells from CML patients resulted in inhibition of IKAROS activity and increased differentiation into basophils (184). Basophils from CML patients express HGF, which promotes CML cell expansion in an autocrine fashion (106). In a mouse model of CML it has been shown that basophil-like leukemia cells promote CML development by producing the chemokine CCL3 (185). In this model basophil-derived CCL3 negatively regulates the proliferation of normal hematopoietic stem/progenitor cells and promotes the expansion of leukemia cells (186). There is also evidence that basophilia is an independent risk factor for evolution of myelodysplastic syndrome to acute myeloid leukemia $(187,188)$.

Peripheral blood basophils have also been associated with certain solid tumors (189). Basopenia appears to be associated with poor prognosis of colorectal cancer $(190,191)$, whereas circulating basophils have no predictive role in breast cancer (192), ovarian cancer (54) and oral squamous cell carcinoma (193). Of note, high relative circulating basophils positively associated with improved outcome in melanoma patients undergoing immunotherapy with nivolumab plus ipilimumab (194). On the other hand, baseline basophil count may predict recurrence in patients with high-grade bladder cancer receiving bacillus Calmette-Guérin (BCG) following resection (195). Finally, in a mouse model of breast cancer, a low percentage of circulating basophils correlated with an increased number of pulmonary metastases, suggesting a protective role of basophils in this model (196).

\section{Basophils and Polycythemia Vera}

Polycythemia vera (PV) is a myeloproliferative neoplasm characterized by clonal stem cell proliferation of erythroid, megakaryocytic, and myeloid cell lines $(197,198)$. An activating Janus kinase 2 (JAK2) mutation (JAK2 ${ }^{\mathrm{V} 617 \mathrm{~F}}$ or exon 12 mutation), leading to an overactive JAK-STAT signaling pathway is found in more than $90 \%$ of PV patients $(199,200)$. Pruritus is a common symptom in PV patients $(198,201)$ and basophil-derived mediators have been implicated in this disorder (202). Absolute basophil counts have been found increased in $\mathrm{JAK} 2{ }^{\mathrm{V} 617 \mathrm{~F}}$-positive PV patients compared to control subjects (203). The expression of CD63, a surface marker of basophil activation, is increased in PV patients with pruritus compared to controls. Finally, PV basophils are hyperresponsive to IL3 compared to basophils from normal donors. Collectively, these findings indicate that $\mathrm{JAK} 2^{\mathrm{V} 617 \mathrm{~F}}$ mutation is associated with hyperreactivity of PV basophils. The latter observation is likely responsible for pruritus in PV patients. Given the role of basophils as major source of Th2 cytokines (e.g., IL-4), we cannot exclude the possibility that the hyperresponsiveness of these cells might play a role in the possible evolution of PV patients. 


\section{Basophils and Ovarian Cancer}

In a recent study, Bax and co-workers examined the role of basophils in ovarian cancer patients (204). They found that higher percentage of circulating basophils from ovarian cancer patients was positively associated with improved overall survival. Furthermore, by protein and gene expression analyses they detected resting (CCR3, CD123, FceRI) and activated basophils $(\mathrm{CD} 63, \mathrm{CD} 203 \mathrm{c})$ in ovarian tumors. Whereas, gene expression for tumor-resident basophils was not associated with patient survival outcomes, gene signatures for activated basophils were positively associated with improved progression-free and overall survival. This study suggests that activated basophils, either in circulation or in tumor, are associated with a survival benefit in ovarian cancer patients.

\section{BASOPHILS AND LUNG CANCER}

It has been well-known for some time that murine (62, 73, $124,125)$ and human (127-131) basophils have a propensity to migrate into the site of inflammation, including the lung. Whether this influx contributes to the supply of tissue resident basophils that promote M2 polarization of lung macrophages (44) remains to be determined. Nonetheless, the evidence that lung-resident basophils acquire the expression of several cytokines due to the exposure to lung-specific signals (e.g., IL-33, GM-CSF), emphasizes the plasticity of these cells. Thus, basophils migrating into tissue may take on completely new roles, based on the cytokine environment they encounter. The observation that the pulmonary microenvironment may condition the transcriptional and functional development of immune cells has recently been extended to the oncological context. Single-cell transcriptomics of human and mouse lung cancers revealed that blood and tumor neutrophils and monocytes strongly differed in their gene expression (205). Interestingly, basophils were present in mouse lung tumors. Lavin and collaborators compared the simultaneous single-cell analysis of the immune compartments in early (stage I) lung adenocarcinoma, non-involved lung tissue (nLung), and peripheral blood of each patient (50). Basophils were present in both solid tumor site and nLung. A percentage of basophils in the tumor were $\mathrm{PD}-\mathrm{L1}^{+}$. This study demonstrates that, as early as in stage I disease, basophils are present in the immune landscape of nLung adenocarcinoma.

In a related example of how the TME can influence basophil function, Schroeder and collaborators demonstrated that highly purified human basophils release histamine and produce IL-4 and IL-13 when co-cultured with the lung carcinoma cell line, A549 (30). Remarkably, these responses required that basophils express IgE, yet occurred independently of allergen, and were suppressed pharmacologically by inhibitors of FceRI signaling. It was subsequently determined that the IgE-binding lectin, galectin-3, expressed on the A549 cells, was responsible for basophil activation (206). In support of these findings, basophils co-cultured with microspheres coated with galectin-3 also secreted IL-4 and IL-13. Galectin-3 is implicated as a biomarker and/or factor contributing to the pathogenesis of a wide range of conditions, including cancer, cardiovascular disease, autoimmunity, wound healing, and chronic inflammation in general (207). Overall, these findings illustrate a novel mechanism by which galectin-3 expressed by human lung carcinoma cells can activate basophils (and likely other cell types) to release several immunoregulatory cytokines and proinflammatory mediators. Additional studies are required to elucidate the exact role of galectin-3 in activating basophils, and how the mediators and cytokines released by these cells contribute to human and experimental lung cancer.

\section{BASOPHILS AND MELANOMA}

The role of basophils has been evaluated in a mouse model of melanoma in which Treg depletion was induced (114). Treg depletion in Foxp3 $3^{\text {DTR }}$ mice was associated with tumor infiltration of basophils and $\mathrm{CD}^{+} \mathrm{T}$ cells leading to rejection of melanoma. Basophils promoted $\mathrm{CD}^{+}$lymphocyte infiltration into the tumor through the production of CCL3 and CCL4. Depletion of basophils, through administration of MAR1 (i.e., anti-FceRI), in Foxp $3^{\text {DTR }}$ melanoma-bearing mice prevented the rejection of melanoma, suggesting a pivotal role of basophils in this model. However, as previously mentioned, MAR1 can also deplete/activate other immune cells (e.g., mast cells, DCs, monocytes) expressing FceRI $(170,171)$. Thus, the possible role of basophils in melanoma will need to be confirmed using the newer genetically engineered basophil-deficient mouse models.

We recently explored the anti-tumor activity of IL-33, a cytokine known to induce tumoricidal functions in eosinophils $(208,209)$ on bone marrow-derived murine basophils. Incubation of basophils with IL-33 upregulated granzyme B mRNA and the surface expression of CD63 (80), indicating phenotypic and functional activation. When IL-33-activated basophils were co-cultured with metastatic B16-F10 melanoma cells, tumor cell-growth was substantially inhibited, as compared to melanoma cells co-cultured with resting basophils. These preliminary findings suggest that, under appropriate stimulation, basophils can acquire tumoricidal properties in vitro. Whether similar activity occurs in vivo remains to be determined, but it is an area of ongoing investigation.

\section{BASOPHILS AND PANCREATIC CANCER}

In the mid 1990s, Ann M. Dvorak showed ultrastructural features of piecemeal degranulation of human basophils in the stroma of pancreatic cancer (11). More recently, Protti and collaborators elegantly investigated the role of basophils and their mediators in experimental and human pancreatic cancer (91). In a large cohort of pancreatic ductal adenocarcinoma (PDAC) patients, they found basophils expressing IL4 in tumor-draining lymph nodes (TDLNs) of PDAC. Importantly, the presence of basophils in TDLNs was an independent negative prognostic biomarker of patient survival after surgery. The authors also examined the possible role of basophils in an orthotopic model of pancreatic cancer using the Mcpt8-Cre basophil deficient (179) and WT mice. At 8 weeks after implant, tumor was found in $80 \%$ WT, but in none of basophil-deficient mice. The authors demonstrated 
the presence of basophils in TDLNs in this model of pancreatic cancer and provided evidence that cancer-associated fibroblasts (CAFs) released TSLP which activated DCs to produce IL-3 from $\mathrm{CD} 4^{+} \mathrm{T}$ cells. IL-3-activated basophils produced substantial amounts of IL-4. It was further determined that DCs and $\mathrm{CD}_{14}{ }^{+}$monocytes produced CCL7 which was responsible for basophil migration into TDLNs. Based on these findings, schematically illustrated in Figure 2, the authors concluded that basophils can favor both Th2 and M2 polarization through the production of IL-4, thus playing a relevant pro-tumorigenic role in PDAC progression. Consistent with this latter concept of IL-4 driving M2 development, our own in vitro studies point to the importance of basophil-derived IL-4 (and IL-13) in promoting M2-like cells (211).

There is compelling evidence that $\mathrm{CD} 4^{+} \mathrm{CD} 25^{+}$Foxp $^{+}$ regulatory $\mathrm{T}$ cells (Tregs) contribute to maintain immune tolerance in the TME $(212,213)$ particularly in pancreatic cancer (214). A recent study has shown that Tregs can induce the expression of activation markers (CD69, CD203c, and CD13) and promote the release of several cytokines (IL-4, IL-8, IL-13) from human basophils (90). Tregs induced basophil activation through the release of IL-3. It has been suggested that Tregs might also promote tumor evasion by activating basophils to augment and sustain Th2 responses in TME by secreting IL-3 (215).

\section{IGE, BASOPHILS AND SKIN CANCER}

$\operatorname{IgE}$ is an ancient and the least abundant circulating immunoglobulin isotype (216). It has been suggested that IgE has evolved to provide protection against helminths (217) and environmental toxins such as venoms (218-220). Moreover, dysregulated $\operatorname{IgE}$ responses can cause a variety of allergic

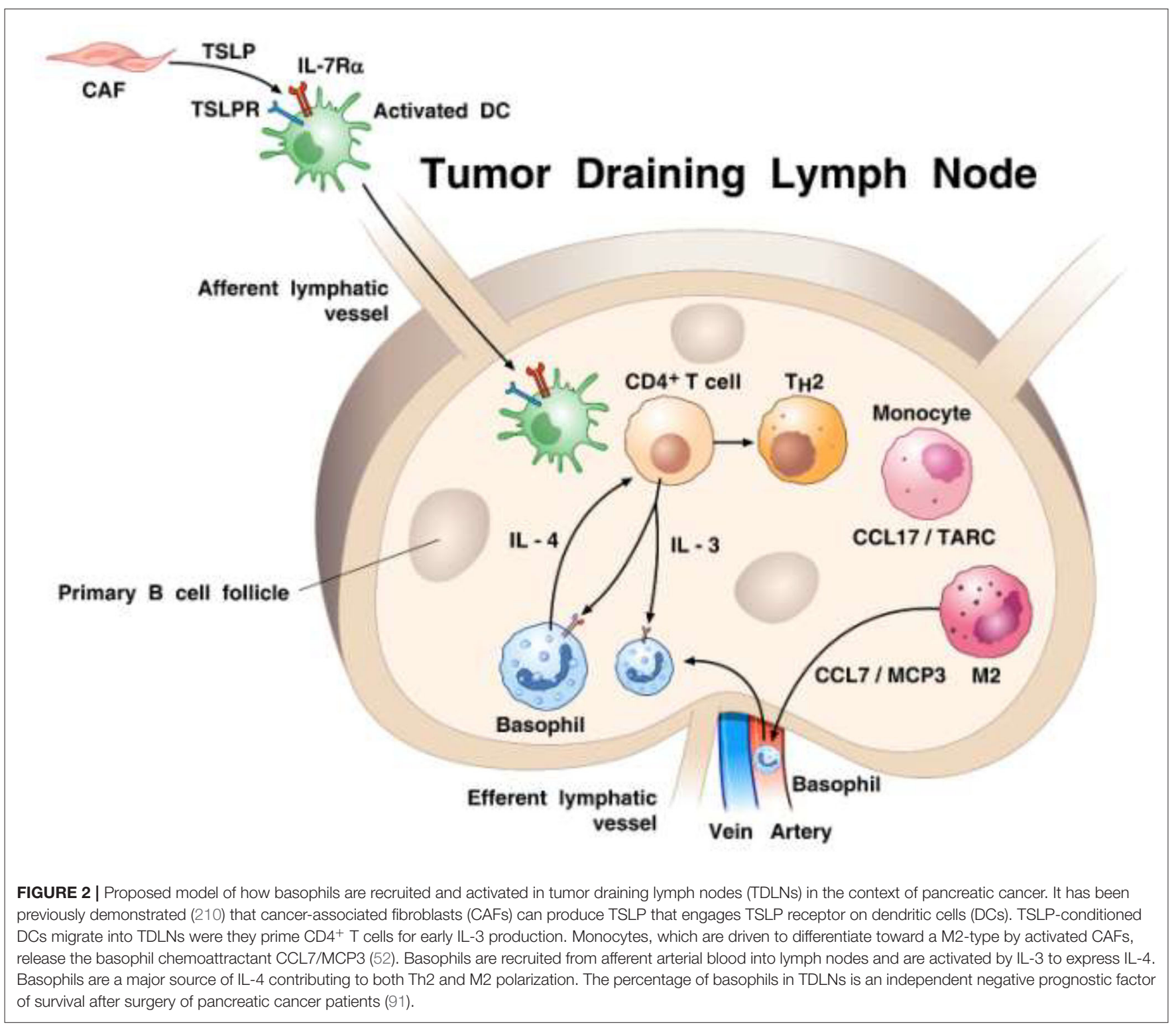


disorders $(221,222)$. IgE binds with very high affinity to FceRI on mast cells and basophils and remains bound to its receptor for the life of these cells (223). It has been demonstrated that once-weekly topical application of the carcinogen 7,12dimethylbenz [a] anthracene (DMBA) to the skin of WT mice led to the development of squamous-cell carcinomas (SCCs) after 8-15 weeks associated with high concentrations of serum IgE and infiltration of IgE-bearing basophils in skin and tumors (224). The same group of investigators extended the previous observation by demonstrating that topical application of the proinflammatory agent 12-0-tetradecanoylphorbol-13-acetate (TPA) (2x a week for 2 weeks) to the skin of WT mice increased serum IgE and IgE-bearing basophils in the skin (62). Using a two-stage inflammation driven model of epithelial carcinogenesis (DMBA and subsequent exposure to TPA) (225), they found that mice lacking $\operatorname{IgE}\left(\lg h 7^{-/-}\right)$were less susceptible to tumor development compared to WT mice. IgE-bearing basophils $\left(\mathrm{Mcpt} 8^{+}\right)$accumulated inside skin tumors of WT mice. In this model, IgE-signaling was necessary for activation and histamine release from basophils. Infiltrating tissue basophils showed expression of Cxcr2, Cxcr4, and Ptger2 (CRTH2, the $\mathrm{PGD}_{2}$ receptor). Blocking CXCR4 with a neutralizing antibody selectively reduced basophil infiltration to the inflamed skin. TSLP and IL-3, abundantly expressed in inflamed skin, increased the surface expression of CXCR4 on basophils, allowing their recruitment to the skin in response to CXCL12. Blocking TSLP and IL-3 simultaneously with neutralizing antibodies abolished basophil recruitment to the skin. The $M c p t 8^{\mathrm{Cre} /+}$ mice, which have normal mast cell numbers but strongly reduced basophils (179), were less susceptible to tumor growth. Together, these results indicate that in this inflammation-driven model of epithelial carcinogenesis, tumor promotion is mediated via FceRI signaling in skin-infiltrating basophils.

\section{CONCLUSIONS AND OUTSTANDING QUESTIONS}

For several decades, basophils were considered erroneously as primary effector cells participating solely in allergic disorders $(226,227)$. The concept that they might possess immunomodulatory roles became more widely appreciated when murine (5) and human basophils were shown to produce a variety of cytokines (e.g., IL-4, IL-3, and IL-13) $(21,89,92,93,97,99,110)$, which at the time, were thought to be made only by Th2 cells. In addition, there is now compelling evidence that human basophils can synthesize several canonical $(57,86,105,106)$ and non-canonical angiogenic factors (151). It has long been known that human (127-131) and mouse (62, 73, 124-126) basophils have a propensity to migrate from peripheral blood into sites of inflammation. Moreover, basophils were identified in human lung $(50)$, gastric $(127,128)$, pancreatic $(11,91)$ and ovarian cancer (204). It was recently shown, at least in mice, that basophils are present in all phases of lung development (44), and display a divergent phenotype from peripheral blood. These resident basophils can favor M2 polarization of lung macrophages, as occurs in several tumors $(132,133)$. Studies are urgently needed to characterize the presence and the state of activation of basophils in TME and their possible roles in early vs. late stages of human and experimental tumors.

Human basophils are a major source of several canonical angiogenic factors such as VEGF-A and VEGF-B (57), HGF (106), ANGPT1 (105), and CXCL8 (86, 89, 90, 228). An elegant study has recently demonstrated that $\mathrm{LTC}_{4}$ and $\mathrm{LTD}_{4}$, also produced by human basophils (83), promote tumor angiogenesis and metastasis through the engagement of $\mathrm{CysLT}_{2} \mathrm{R}$ on endothelial cells (151). Collectively, these findings suggest that further in vitro and in vivo investigations should evaluate the roles of canonical and non-canonical angiogenic factors produced by basophils in experimental and human tumors.

Activated human and mouse basophils release BETs (116118). There is mounting evidence that extracellular DNA traps have multiple effects in cancer (160) favoring tumor growth (167), awakening dormant cancer cells (165), and promoting metastasis in mouse models and in humans $(161,164)$. Further studies should evaluate the presence of BETs in experimental and human cancers and whether basophil extracellular traps modulate tumor growth and the formation of metastasis in vivo.

There are contemporary and developing models/techniques that should greatly facilitate this area of investigation. For example, basophil-deficient mice are powerful models for analyzing basophil functions in vivo, but, in some instances, have produced erroneous findings. For example, models using antibody-depleted basophils $(168,169)$ can often result in the activation of other immune cells $(170,171)$. Indeed, such models provided highly controversial results on the role of basophils as APCs $(95,170,172,173,229,230)$. It is therefore not surprising that basophils may appear to play a protective (114) or a pro-tumorigenic role $(62,91)$ depending on the experimental model utilized. In general, mouse models with constitutive or inducible basophils depletion should be preferred, but need to take into consideration that even new mouse mutants can have hematologic abnormalities (177) and/or show incomplete removal of basophils. Studies attempting to evaluate basophil functions in a complex and heterogeneous disorder, such as cancer should be performed using multiple genetically engineered models of basophil deficiency.

In conclusion, the last years have witnessed exceptional progress in our understanding of basophil biology. Recent studies have demonstrated that basophils are present in the immune landscape of human $(50,91,204)$ and experimental $(62,91)$ tumors, play a role in lung development and M2 macrophage polarization (44), and participate in canonical (57, 105, 106, 145) and non-canonical angiogenesis (151), and release BETs $(117,118)$. Further investigations are required before we unravel the mysterious role of basophils in experimental cancer and, more importantly, in humans. The elucidation of basophil role in tumor immunity will require studies of increasing complexity beyond those assessing their microlocalization. High dimensional analysis, particularly single-cell RNA-seq of immune landscape of human and experimental tumors will be of paramount importance in characterizing basophil role in different human and experimental cancers. 


\section{AUTHOR CONTRIBUTIONS}

All authors contributed to reviewing the current literature and writing of the manuscript.

\section{FUNDING}

This work was supported in part by grants from the CISI-Lab Project (University of Naples Federico II), TIMING Project (Regione Campania), from AIRC IG21366 to GS and NIAID, and NIH grants AI115703 and AI141486 to JS.

\section{REFERENCES}

1. Ehrlich P. Ueber die specifischen Granulationen des Blutes. Archiv fuer Anatomie und Physiologie: Physiologische Abteilung. (1879) 3:571-9.

2. Ehrlich P. Beitrage sur Theorie und Praxis der Histologischen Farbung (Ph.D. Thesis). University of Leipzig, Leipzig, Germany (1878).

3. Dvorak AM, Newball HH, Dvorak HF, Lichtenstein LM. Antigen-induced IgE-mediated degranulation of human basophils. Lab Invest. (1980) 43:12639.

4. Dvorak HF, Dvorak AM, Simpson BA, Richerson HB, Leskowitz S, Karnovsky MJ. Cutaneous basophil hypersensitivity. II. A light and electron microscopic description. J Exp Med. (1970) 132:558-82. doi: 10.1084/jem.132.3.558

5. Seder RA, Paul WE, Dvorak AM, Sharkis SJ, Kagey-Sobotka A, Niv Y, et al. Mouse splenic and bone marrow cell populations that express high-affinity Fc epsilon receptors and produce interleukin 4 are highly enriched in basophils. Proc Natl Acad Sci USA. (1991) 88:28359. doi: 10.1073/pnas.88.7.2835

6. Dvorak AM, Nabel G, Pyne K, Cantor H, Dvorak HF, Galli SJ. Ultrastructural identification of the mouse basophil. Blood. (1982) 59:127985. doi: 10.1182/blood.V59.6.1279.bloodjournal5961279

7. Hardin JH, Spicer SS. Ultrastructural localization of dialyzed iron-reactive mucosubstance in rabbit heterophils, basophils, and eosinophils. J Cell Biol. (1971) 48:368-86. doi: 10.1083/jcb.48.2.368

8. Dvorak AM, Monahan-Earley RA, Estrella P, Kissell S, Donahue RE. Ultrastructure of monkey peripheral blood basophils stimulated to develop in vivo by recombinant human interleukin 3. Lab Invest. (1989) 61:677-90.

9. Varricchi G, de Paulis A, Marone G, Galli SJ. Future needs in mast cell biology. Int J Mol Sci. (2019) 20:4397. doi: 10.3390/ijms20184397

10. Varricchi G, Marone G. Mast cells: fascinating but still elusive after 140 years from their discovery. Int J Mol Sci. (2020) 21:464. doi: 10.3390/ijms21020464

11. Dvorak AM. Ultrastructural analysis of human mast cells and basophils. Chem Immunol. (1995) 61:1-33. doi: 10.1159/000424579

12. Marone G, Borriello F, Varricchi G, Genovese A, Granata F. Basophils: historical reflections and perspectives. Chem Immunol Allergy. (2014) 100:172-92. doi: 10.1159/000358734

13. Varricchi G, Raap U, Rivellese F, Marone G, Gibbs BF. Human mast cells and basophils-How are they similar how are they different? Immunol Rev. (2018) 282:8-34. doi: 10.1111/imr.12627

14. Galli SJ, Tsai M, Marichal T, Tchougounova E, Reber LL, Pejler G. Approaches for analyzing the roles of mast cells and their proteases in vivo. Adv Immunol. (2015) 126:45-127. doi: 10.1016/bs.ai.2014.11.002

15. Metcalfe DD, Pawankar R, Ackerman SJ, Akin C, Clayton F, Falcone $\mathrm{FH}$, et al. Biomarkers of the involvement of mast cells, basophils and eosinophils in asthma and allergic diseases. World Allergy Organ J. (2016) 9:7. doi: 10.1186/s40413-016-0094-3

16. Dvorak AM, Schulman ES, Peters SP, MacGlashan DW, Jr, Newball HH, et al. Immunoglobulin E-mediated degranulation of isolated human lung mast cells. Lab Invest. (1985) 53:45-56.

\section{ACKNOWLEDGMENTS}

The authors apologize to the many researchers who have contributed importantly to this field and whose work was not cited because of space and citations restrictions. The authors are grateful to Ann M. Dvorak for her extraordinary contribution to the characterization of human and murine basophils and for providing the photos of Figure 1. The authors thank Dr. Gjada Criscuolo for a critical reading of the manuscript, scientists of CISI-Laboratory and Schiavoni Laboratory not listed as authors for invaluable collaboration to the work reviewed, and the medical graphic artist Fabrizio Fiorbianco for the elaboration of Figure 2.

17. Patella V, Marino I, Lamparter B, Arbustini E, Adt M, Marone G. Human heart mast cells. Isolation, purification, ultrastructure, and immunologic characterization. J Immunol. (1995) 154:2855-65.

18. Marone G, Triggiani M, Genovese A, De Paulis A. Role of human mast cells and basophils in bronchial asthma. Adv Immunol. (2005) 88:97160. doi: 10.1016/S0065-2776(05)88004-6

19. Dvorak AM. The mouse basophil, a rare and rarely recognized granulocyte. Blood. (2000) 96:16167. doi: 10.1182/blood.V96.4.1616.h8001608e_1616_1617

20. Arinobu Y, Iwasaki H, Gurish MF, Mizuno S, Shigematsu H, Ozawa H, et al. Developmental checkpoints of the basophil/mast cell lineages in adult murine hematopoiesis. Proc Natl Acad Sci USA. (2005) 102:1810510. doi: 10.1073/pnas.0509148102

21. Schroeder JT, Chichester KL, Bieneman AP. Human basophils secrete IL-3: evidence of autocrine priming for phenotypic and functional responses in allergic disease. J Immunol. (2009) 182:2432-8. doi: 10.4049/jimmunol.0801782

22. Kirshenbaum AS, Goff JP, Dreskin SC, Irani AM, Schwartz LB, Metcalfe DD. IL-3-dependent growth of basophil-like cells and mastlike cells from human bone marrow. J Immunol. (1989) 142:2424-9.

23. Valent P, Besemer J, Muhm M, Majdic O, Lechner K, Bettelheim P. Interleukin 3 activates human blood basophils via high-affinity binding sites. Proc Natl Acad Sci USA. (1989) 86:5542-6. doi: 10.1073/pnas.8 6.14 .5542

24. Valent P, Schmidt G, Besemer J, Mayer P, Zenke G, Liehl E, et al. Interleukin3 is a differentiation factor for human basophils. Blood. (1989) 73:17639. doi: 10.1182/blood.V73.7.1763.bloodjournal7371763

25. Yoshimoto T, Nakanishi K. Generation and characterization of mouse basophils from bone marrow and purification of basophils from spleen. Curr Protoc Immunol. (2012) Chapter 3, Unit 3 24. doi: 10.1002/0471142735.im0324s98

26. Siracusa MC, Saenz SA, Hill DA, Kim BS, Headley MB, Doering TA, et al. TSLP promotes interleukin-3-independent basophil haematopoiesis and type 2 inflammation. Nature. (2011) 477:229-33. doi: 10.1038/nature10329

27. Siracusa MC, Wojno ED, Artis D. Functional heterogeneity in the basophil cell lineage. Adv Immunol. (2012) 115:14159. doi: 10.1016/B978-0-12-394299-9.00005-9

28. Salter BM, Oliveria JP, Nusca G, Smith SG, Watson RM, Comeau M, et al. Thymic stromal lymphopoietin activation of basophils in patients with allergic asthma is IL-3 dependent. J Allergy Clin Immunol. (2015) 136:1636-44. doi: 10.1016/j.jaci.2015.03.039

29. Salabert-Le Guen N, Hemont C, Delbove A, Poli C, Braudeau C, Fantou A, et al. Thymic stromal lymphopoietin does not activate human basophils. J Allergy Clin Immunol. (2018) 141:1476-9 e1476. doi: 10.1016/j.jaci.2017.11.012

30. Schroeder JT, Bieneman AP. Activation of Human Basophils by A549 Lung Epithelial Cells Reveals a Novel IgE-dependent response independent of allergen. J Immunol. (2017) 199:855-65. doi: 10.4049/jimmunol.17 00055 
31. Afferni C, Buccione C, Andreone S, Galdiero MR, Varricchi G, Marone G, et al. The pleiotropic immunomodulatory functions of IL33 and its implications in tumor immunity. Front Immunol. (2018) 9:2601. doi: 10.3389/fimmu.2018.02601

32. Varricchi G, Pecoraro A, Marone G, Criscuolo G, Spadaro G, Genovese A, et al. Thymic stromal lymphopoietin isoforms, inflammatory disorders, and cancer. Front Immunol. (2018) 9:1595. doi: 10.3389/fimmu.2018.01595

33. Daeron M. Innate myeloid cells under the control of adaptive immunity: the example of mast cells and basophils. Curr Opin Immunol. (2016) 38:1018. doi: 10.1016/j.coi.2015.12.004

34. Malveaux FJ, Conroy MC, Adkinson NF Jr, Lichtenstein LM. IgE receptors on human basophils. Relationship to serum IgE concentration. J Clin Invest. (1978) 62:176-81. doi: 10.1172/JCI109103

35. Pellefigues C, Mehta P, Prout MS, Naidoo K, Yumnam B, Chandler $\mathrm{J}$, et al. The Basoph8 mice enable an unbiased detection and a conditional depletion of basophils. Front Immunol. (2019) 10:2143. doi: 10.3389/fimmu.2019.02143

36. Mukai K, Gaudenzio N, Gupta S, Vivanco N, Bendall SC, Maecker HT, et al. Assessing basophil activation by using flow cytometry and mass cytometry in blood stored 24 hours before analysis. $J$ Allergy Clin Immunol. (2017) 139:889-99 e811. doi: 10.1016/j.jaci.20 16.04.060

37. MacGlashan D Jr. Expression of CD203c and CD63 in human basophils: relationship to differential regulation of piecemeal and anaphylactic degranulation processes. Clin Exp Allergy. (2010) 40:1365-77. doi: 10.1111/j.1365-2222.2010.03572.x

38. MacGlashan DW Jr. Basophil activation testing. J Allergy Clin Immunol. (2013) 132:777-87. doi: 10.1016/j.jaci.2013.06.038

39. Tsai SH, Kinoshita M, Kusu T, Kayama H, Okumura R, Ikeda K, et al. The ectoenzyme E-NPP3 negatively regulates ATP-dependent chronic allergic responses by basophils and mast cells. Immunity. (2015) 42:27993. doi: 10.1016/j.immuni.2015.01.015

40. Cassard L, Jonsson F, Arnaud S, Daeron M. Fcgamma receptors inhibit mouse and human basophil activation. J Immunol. (2012) 189:29953006. doi: 10.4049/jimmunol.1200968

41. Meknache N, Jonsson F, Laurent J, Guinnepain MT, Daeron M. Human basophils express the glycosylphosphatidylinositol-anchored low-affinity IgG receptor FcgammaRIIIB (CD16B). J Immunol. (2009) 182:254250. doi: 10.4049/jimmunol.0801665

42. Lantz CS, Boesiger J, Song CH, Mach N, Kobayashi T, Mulligan RC, et al. Role for interleukin-3 in mast-cell and basophil development and in immunity to parasites. Nature. (1998) 392:90-3. doi: 10.1038/32190

43. Kampfer SS, Odermatt A, Dahinden CA, Fux M. Late IL-3induced phenotypic and functional alterations in human basophils require continuous IL-3 receptor signaling. I Leukoc Biol. (2017) 101:227-38. doi: 10.1189/jlb.2A0715-292RR

44. Cohen M, Giladi A, Gorki AD, Solodkin DG, Zada M, Hladik A, et al. Lung single-cell signaling interaction map reveals basophil role in macrophage imprinting. Cell. (2018) 175:1031-44 e1018. doi: 10.1016/j.cell.2018.09.009

45. Pecaric-Petkovic T, Didichenko SA, Kaempfer S, Spiegl N, Dahinden CA. Human basophils and eosinophils are the direct target leukocytes of the novel IL-1 family member IL-33. Blood. (2009) 113:152634. doi: 10.1182/blood-2008-05-157818

46. Smithgall MD, Comeau MR, Yoon BR, Kaufman D, Armitage R, Smith DE. IL-33 amplifies both Th1- and Th2-type responses through its activity on human basophils, allergen-reactive Th2 cells, iNKT and NK cells. Int Immunol. (2008) 20:1019-30. doi: 10.1093/intimm/dxn060

47. Suzukawa M, Iikura M, Koketsu R, Nagase H, Tamura C, Komiya A, et al. An IL-1 cytokine member, IL-33, induces human basophil activation via its ST2 receptor. J Immunol. (2008) 181:5981-9. doi: 10.4049/jimmunol.181.9.5981

48. Burgi B, Otten UH, Ochensberger B, Rihs S, Heese K, Ehrhard PB, et al. Basophil priming by neurotrophic factors. Activation through the trk receptor. J Immunol. (1996) 157:5582-8.

49. Sin AZ, Roche EM, Togias A, Lichtenstein LM, Schroeder JT. Nerve growth factor or IL-3 induces more IL-13 production from basophils of allergic subjects than from basophils of nonallergic subjects. J Allergy Clin Immunol. (2001) 108:387-93. doi: 10.1067/mai.2001.117459
50. Lavin Y, Kobayashi S, Leader A, Amir ED, Elefant N, Bigenwald C, et al. Innate immune landscape in early lung adenocarcinoma by paired single-cell analyses. Cell. (2017) 169:750-65 e717. doi: 10.1016/j.cell.2017.04.014

51. Pellefigues C, Dema B, Lamri Y, Saidoune F, Chavarot N, Loheac C, et al. Prostaglandin D2 amplifies lupus disease through basophil accumulation in lymphoid organs. Nat Commun. (2018) 9:725. doi: 10.1038/s41467-018-03129-8

52. Dahinden CA, Geiser T, Brunner T, von Tscharner V, Caput D, Ferrara P, et al. Monocyte chemotactic protein 3 is a most effective basophil- and eosinophil-activating chemokine. J Exp Med. (1994) 179:7516. doi: 10.1084/jem.179.2.751

53. Mack M, Schneider MA, Moll C, Cihak J, Bruhl H, Ellwart JW, et al. Identification of antigen-capturing cells as basophils. J Immunol. (2005) 174:735-41. doi: 10.4049/jimmunol.174.2.735

54. Khan ANH, Emmons TR, Wong JT, Alqassim E, Singel KL, Mark J, et al. Quantification of early-stage myeloid-derived suppressor cells in cancer requires excluding basophils. Cancer Immunol Res. (2020) 8:81928. doi: 10.1158/2326-6066.CIR-19-0556

55. Satoh T, Moroi R, Aritake K, Urade Y, Kanai Y, Sumi K, et al. Prostaglandin D2 plays an essential role in chronic allergic inflammation of the skin via CRTH2 receptor. J Immunol. (2006) 177:2621-9. doi: 10.4049/jimmunol.177.4.2621

56. Shiratori I, Yamaguchi M, Suzukawa M, Yamamoto K, Lanier LL, Saito $\mathrm{T}$, et al. Down-regulation of basophil function by human CD200 and human herpesvirus-8 CD200. J Immunol. (2005) 175:4441-9. doi: 10.4049/jimmunol.175.7.4441

57. de Paulis A, Prevete N, Fiorentino I, Rossi FW, Staibano S, Montuori N, et al. Expression and functions of the vascular endothelial growth factors and their receptors in human basophils. J Immunol. (2006) 177:732231. doi: 10.4049/jimmunol.177.10.7322

58. Cassard L, Sperber K, Buivan TP, Cotillard A, Bourdet-Sicard R, Albert $\mathrm{ML}$, et al. Basophils from allergic patients are neither hyperresponsive to activation signals nor hyporesponsive to inhibition signals. J Allergy Clin Immunol. (2018) 142:1548-57. doi: 10.1016/j.jaci.2017.11.053

59. Reimer JM, Magnusson S, Juremalm M, Nilsson G, Hellman L, Wernersson $\mathrm{S}$. Isolation of transcriptionally active umbilical cord blood-derived basophils expressing Fc epsilon RI, HLA-DR and CD203c. Allergy. (2006) 61:106370. doi: 10.1111/j.1398-9995.2006.01149.x

60. Jonsson F, Daeron M. Mast cells and company. Front Immunol. (2012) 3:16. doi: 10.3389/fimmu.2012.00016

61. Hausmann OV, Gentinetta T, Fux M, Ducrest S, Pichler WJ, Dahinden CA. Robust expression of CCR3 as a single basophil selection marker in flow cytometry. Allergy. (2011) 66:85-91. doi: 10.1111/j.1398-9995.2010.02431.x

62. Hayes MD, Ward S, Crawford G, Seoane RC, Jackson WD, Kipling D, et al. Inflammation-induced IgE promotes epithelial hyperplasia and tumour growth. Elife. (2020) 9: e51862. doi: 10.7554/eLife.51862

63. Jinquan $\mathrm{T}$, Jacobi $\mathrm{HH}$, Jing C, Reimert CM, Quan S, Dissing $\mathrm{S}$, et al. Chemokine stromal cell-derived factor 1alpha activates basophils by means of CXCR4. J Allergy Clin Immunol. (2000) 106:313-20. doi: 10.1067/mai.2000.108108

64. Hirai H, Tanaka K, Yoshie O, Ogawa K, Kenmotsu K, Takamori Y, et al. Prostaglandin D2 selectively induces chemotaxis in $\mathrm{T}$ helper type 2 cells, eosinophils, and basophils via seven-transmembrane receptor CRTH2. J Exp Med. (2001) 193:255-61. doi: 10.1084/jem.193.2.255

65. Monneret G, Boumiza R, Gravel S, Cossette C, Bienvenu J, Rokach J, et al. Effects of prostaglandin $\mathrm{D}(2)$ and 5-lipoxygenase products on the expression of CD203c and CD11b by basophils. J Pharmacol Exp Ther. (2005) 312:62734. doi: 10.1124/jpet.104.074823

66. Torrero MN, Larson D, Hubner MP, Mitre E. CD200R surface expression as a marker of murine basophil activation. Clin Exp Allergy. (2009) 39:3619. doi: 10.1111/j.1365-2222.2008.03154.x

67. Bachelet I, Munitz A, Moretta A, Moretta L, Levi-Schaffer F. The inhibitory receptor IRp60 (CD300a) is expressed and functional on human mast cells. J Immunol. (2005) 175:7989-95. doi: 10.4049/jimmunol.175.12.7989

68. Borrego F. The CD300 molecules: an emerging family of regulators of the immune system. Blood. (2013) 121:195160. doi: 10.1182/blood-2012-09-435057 
69. Gibbs BF, Sabato V, Bridts CH, Ebo DG, Ben-Zimra M, Levi-Schaffer F. Expressions and inhibitory functions of CD300a receptors on purified human basophils. Exp Dermatol. (2012) 21:884-6. doi: 10.1111/exd.12018

70. Zenarruzabeitia O, Vitalle J, Terren I, Orrantia A, Astigarraga I, Dopazo $\mathrm{L}$, et al. CD300c costimulates IgE-mediated basophil activation, and its expression is increased in patients with cow's milk allergy. J Allergy Clin Immunol. (2019) 143:700-11 e705. doi: 10.1016/j.jaci.2018.05.022

71. Qi Y, Operario DJ, Oberholzer CM, Kobie JJ, Looney RJ, Georas $\mathrm{SN}$, et al. Human basophils express amphiregulin in response to T cell-derived IL-3. J Allergy Clin Immunol. (2010) 126:1260-6 e1264. doi: 10.1016/j.jaci.2010.08.040

72. Bando T, Fujita S, Nagano N, Yoshikawa S, Yamanishi Y, Minami $\mathrm{M}$, et al. Differential usage of COX-1 and COX-2 in prostaglandin production by mast cells and basophils. Biochem Biophys Rep. (2017) 10:827. doi: 10.1016/j.bbrep.2017.03.004

73. Piliponsky AM, Shubin NJ, Lahiri AK, Truong P, Clauson M, Niino K, et al. Basophil-derived tumor necrosis factor can enhance survival in a sepsis model in mice. Nat Immunol. (2019) 20:129-40. doi: 10.1038/s41590-018-0288-7

74. Shibata S, Miyake K, Tateishi T, Yoshikawa S, Yamanishi Y, Miyazaki Y, et al. Basophils trigger emphysema development in a murine model of COPD through IL-4-mediated generation of MMP-12-producing macrophages. Proc Natl Acad Sci USA. (2018) 115:13057-62. doi: 10.1073/pnas.1813927115

75. Eberle JU, Voehringer D. Role of basophils in protective immunity to parasitic infections. Semin Immunopathol. (2016) 38:605-13. doi: 10.1007/s00281-016-0563-3

76. Eberle JU, Radtke D, Nimmerjahn F, Voehringer D. Eosinophils mediate basophil-dependent allergic skin inflammation in mice. J Invest Dermatol. (2019) 139:1957-65 e1952. doi: 10.1016/j.jid.2019.03.1129

77. McEuen AR, Calafat J, Compton SJ, Easom NJ Buckley MG, Knol EF, et al. Mass, charge, and subcellular localization of a unique secretory product identified by the basophil-specific antibody BB1. J Allergy Clin Immunol. (2001) 107:842-8. doi: 10.1067/mai.2001.114650

78. Jogie-Brahim S, Min HK, Fukuoka Y, Xia HZ, Schwartz LB. Expression of alpha-tryptase and beta-tryptase by human basophils. J Allergy Clin Immunol. (2004) 113:1086-92. doi: 10.1016/j.jaci.2004.02.032

79. Tschopp CM, Spiegl N, Didichenko S, Lutmann W, Julius P, Virchow JC, et al. Granzyme B, a novel mediator of allergic inflammation: its induction and release in blood basophils and human asthma. Blood. (2006) 108:22909. doi: 10.1182/blood-2006-03-010348

80. Marone G, Gambardella AR, Mattei F, Mancini J, Schiavoni G, Varricchi G. Basophils in Tumor Microenvironment and Surroundings. Adv Exp Med Biol. (2020) 1224:21-34. doi: 10.1007/978-3-030-35723-8_2

81. Motomura Y, Morita H, Moro K, Nakae S, Artis D, Endo TA, et al. Basophil-derived interleukin-4 controls the function of natural helper cells, a member of ILC2s, in lung inflammation. Immunity. (2014) 40:75871. doi: 10.1016/j.immuni.2014.04.013

82. Voskoboinik I, Whisstock JC, Trapani JA. Perforin and granzymes: function, dysfunction and human pathology. Nat Rev Immunol. (2015) 15:388400. doi: $10.1038 /$ nri3839

83. MacGlashan DW, Jr, Peters SP, Warner J, Lichtenstein LM. Characteristics of human basophil sulfidopeptide leukotriene release: releasability defined as the ability of the basophil to respond to dimeric cross-links. J Immunol. (1986) 136:2231-9.

84. Ugajin T, Satoh T, Kanamori T, Aritake K, Urade Y, Yokozeki H. FcepsilonRI, but not FcgammaR, signals induce prostaglandin D2 and E2 production from basophils. Am J Pathol. (2011) 179:775-82. doi: 10.1016/j.ajpath.2011.04.023

85. Marone G, Galdiero MR, Pecoraro A, Pucino V, Criscuolo G, Triassi M, et al. Prostaglandin D2 receptor antagonists in allergic disorders: safety, efficacy, and future perspectives. Expert Opin Investig Drugs. (2019) 28:7384. doi: 10.1080/13543784.2019.1555237

86. Schroeder JT. Basophils: emerging roles in the pathogenesis of allergic disease. Immunol Rev. (2011) 242:14460. doi: 10.1111/j.1600-065X.2011.01023.x

87. Brunner $\mathrm{T}$, Heusser $\mathrm{CH}$, Dahinden CA. Human peripheral blood basophils primed by interleukin 3 (IL-3) produce IL-4 in response to immunoglobulin E receptor stimulation. J Exp Med. (1993) 177:60511. doi: 10.1084/jem.177.3.605

88. Chen $\mathrm{K}, \mathrm{Xu} \mathrm{W}$, Wilson $\mathrm{M}, \mathrm{He} \mathrm{B}$, Miller NW, Bengten E, et al. Immunoglobulin $\mathrm{D}$ enhances immune surveillance by activating antimicrobial, proinflammatory and B cell-stimulating programs in basophils. Nat Immunol. (2009) 10:889-98. doi: 10.1038/ni.1748

89. Galeotti C, Stephen-Victor E, Karnam A, Das M, Gilardin L, Maddur MS, et al. Intravenous immunoglobulin induces IL-4 in human basophils by signaling through surface-bound IgE. J Allergy Clin Immunol. (2019) 144:524-35 e528. doi: 10.1016/j.jaci.2018.10.064

90. Sharma M, Das M, Stephen-Victor E, Galeotti C, Karnam A, Maddur MS, et al. Regulatory $\mathrm{T}$ cells induce activation rather than suppression of human basophils. Sci Immunol. (2018) 3:eaan0829. doi: 10.1126/sciimmunol.aan0829

91. De Monte L, Wormann S, Brunetto E, Heltai S, Magliacane G, Reni M, et al. Basophil recruitment into tumor-draining lymph nodes correlates with Th2 inflammation and reduced survival in pancreatic cancer patients. Cancer Res. (2016) 76:1792-803. doi: 10.1158/0008-5472.CAN-15-1801-T

92. Patella V, Florio G, Petraroli A, Marone G. HIV-1 gp120 induces IL-4 and IL-13 release from human Fc epsilon RI+ cells through interaction with the VH3 region of IgE. J Immunol. (2000) 164:58995. doi: 10.4049/jimmunol.164.2.589

93. Patella V, Giuliano A, Bouvet JP, Marone G. Endogenous superallergen protein Fv induces IL-4 secretion from human Fc epsilon RI+ cells through interaction with the VH3 region of IgE. J Immunol. (1998) 161:5647-55.

94. Genovese A, Borgia G, Bjorck L, Petraroli A, de Paulis A, Piazza M, et al. Immunoglobulin superantigen protein L induces IL-4 and IL13 secretion from human Fc epsilon RI+ cells through interaction with the kappa light chains of IgE. J Immunol. (2003) 170:185461. doi: 10.4049/jimmunol.170.4.1854

95. Sokol CL, Chu NQ, Yu S, Nish SA, Laufer TM, Medzhitov R. Basophils function as antigen-presenting cells for an allergen-induced $\mathrm{T}$ helper type 2 response. Nat Immunol. (2009) 10:713-20. doi: 10.1038/ni.1738

96. Schroeder JT, MacGlashan DW Jr, Kagey-Sobotka A, White JM, Lichtenstein LM. IgE-dependent IL-4 secretion by human basophils. The relationship between cytokine production and histamine release in mixed leukocyte cultures. J Immunol. (1994) 153:1808-17.

97. Redrup AC, Howard BP, MacGlashan DW, Jr, Kagey-Sobotka A, Lichtenstein LM, et al. Differential regulation of IL-4 and IL-13 secretion by human basophils: their relationship to histamine release in mixed leukocyte cultures. J Immunol. (1998) 160:1957-64.

98. Gibbs BF, Haas H, Falcone FH, Albrecht C, Vollrath IB, Noll T, et al. Purified human peripheral blood basophils release interleukin-13 and preformed interleukin-4 following immunological activation. Eur J Immunol. (1996) 26:2493-8. doi: 10.1002/eji.1830261033

99. Ochensberger B, Daepp GC, Rihs S, Dahinden CA. Human blood basophils produce interleukin-13 in response to IgEreceptor-dependent and -independent activation. Blood. (1996) 88:3028-37. doi: 10.1182/blood.V88.8.3028.bloodjournal 8883028

100. Li H, Sim TC, Alam R. IL-13 released by and localized in human basophils. $J$ Immunol. (1996) 156:4833-8.

101. Yuk CM, Park HJ, Kwon BI, Lah SJ, Chang J, Kim JY, et al. Basophil-derived IL-6 regulates TH17 cell differentiation and CD4 T cell immunity. Sci Rep. (2017) 7:41744. doi: 10.1038/srep41744

102. Falkencrone S, Poulsen LK, Bindslev-Jensen C, Woetmann A, Odum N, Poulsen BC, et al. IgE-mediated basophil tumour necrosis factor alpha induces matrix metalloproteinase-9 from monocytes. Allergy. (2013) 68:614620. doi: 10.1111/all.12143

103. Italiani P, Boraschi D. From Monocytes to M1/M2 Macrophages: Phenotypical vs. Functional Differentiation. Front Immunol. (2014) 5:514. doi: 10.3389/fimmu.2014.00514

104. Guilliams M, Mildner A, Yona S. Developmental and functional heterogeneity of $9568^{*}+$ Monocytes. Immunity. (2018) 49:595613. doi: 10.1016/j.immuni.2018.10.005

105. Prevete N, Staiano RI, Granata F, Detoraki A, Necchi V, Ricci V, et al. Expression and function of Angiopoietins and their tie receptors in human basophils and mast cells. J Biol Regul Homeost Agents. (2013) 27:827-39. 
106. Cerny-Reiterer S, Ghanim V, Hoermann G, Aichberger KJ, Herrmann $\mathrm{H}$, Muellauer L, et al. Identification of basophils as a major source of hepatocyte growth factor in chronic myeloid leukemia: a novel mechanism of BCR-ABL1-independent disease progression. Neoplasia. (2012) 14:57284. doi: $10.1593 /$ neo. 12724

107. Zaiss DMW, Gause WC, Osborne LC, Artis D. Emerging functions of amphiregulin in orchestrating immunity, inflammation, and tissue repair. Immunity. (2015) 42:216-26. doi: 10.1016/j.immuni.2015.01.020

108. Meulenbroeks C, van Weelden H, Schwartz C, Voehringer D, Redegeld FAM, Rutten V, et al. Basophil-derived amphiregulin is essential for UVB irradiation-induced immune suppression. J Invest Dermatol. (2015) 135:2228. doi: 10.1038/jid.2014.329

109. Rignault-Bricard R, Machavoine F, Mecheri S, Hermine O, Schneider E, Dy $M$, et al. IL-3-producing basophils are required to exacerbate airway hyperresponsiveness in a murine inflammatory model. Allergy. (2018) 73:2342-51. doi: 10.1111/all.13480

110. MacGlashan D Jr, White JM, Huang SK, Ono SJ, Schroeder JT, et al. Secretion of IL-4 from human basophils. The relationship between IL-4 mRNA and protein in resting and stimulated basophils. J Immunol. (1994) 152:3006-16.

111. Schroeder JT, Lichtenstein LM, MacDonald SM. An immunoglobulin Edependent recombinant histamine-releasing factor induces interleukin4 secretion from human basophils. J Exp Med. (1996) 183:12651270. doi: 10.1084/jem.183.3.1265

112. Oliver JM, Tarleton CA, Gilmartin L, Archibeque T, Qualls CR, Diehl L, et al. Reduced FcepsilonRI-mediated release of asthma-promoting cytokines and chemokines from human basophils during omalizumab therapy. Int Arch Allergy Immunol. (2010) 151:275-84. doi: 10.1159/000250436

113. Raap U, Gehring M, Kleiner S, Rudrich U, Eiz-Vesper B, Haas H, et al. Human basophils are a source of - and are differentially activated by - IL-31. Clin Exp Allergy. (2017) 47:499-508. doi: 10.1111/cea.12875

114. Sektioglu IM, Carretero R, Bulbuc N, Bald T, Tuting T, Rudensky AY, et al. Basophils promote tumor rejection via chemotaxis and infiltration of CD8+ T cells. Cancer Res. (2017) 77:291-302. doi: 10.1158/0008-5472.CAN-16-0993

115. Marone G, Casolaro V, Paganelli R, Quinti I. IgG anti-IgE from atopic dermatitis induces mediator release from basophils and mast cells. J Invest Dermatol. (1989) 93:246-52. doi: 10.1111/1523-1747.ep122 77582

116. Morshed M, Hlushchuk R, Simon D, Walls AF, Obata-Ninomiya $\mathrm{K}$, Karasuyama $\mathrm{H}$, et al. NADPH oxidase-independent formation of extracellular DNA traps by basophils. J Immunol. (2014) 192:531423. doi: 10.4049/jimmunol.1303418

117. Yousefi S, Morshed M, Amini P, Stojkov D, Simon D, von Gunten S, et al. Basophils exhibit antibacterial activity through extracellular trap formation. Allergy. (2015) 70:1184-8. doi: 10.1111/all.12662

118. Schorn C, Janko C, Latzko M, Chaurio R, Schett G, Herrmann M. Monosodium urate crystals induce extracellular DNA traps in neutrophils, eosinophils, and basophils but not in mononuclear cells. Front Immunol. (2012) 3:277. doi: 10.3389/fimmu.2012.00277

119. Voehringer D. Protective and pathological roles of mast cells and basophils. Nat Rev Immunol. (2013) 13:362-75. doi: 10.1038/n ri3427

120. Nakashima C, Otsuka A, Kabashima K. Recent advancement in the mechanism of basophil activation. J Dermatol Sci. (2018) 91:3-8. doi: 10.1016/j.jdermsci.2018.03.007

121. Siracusa MC, Kim BS, Spergel JM, Artis D. Basophils and allergic inflammation. J Allergy Clin Immunol. (2013) 132:789-801; quiz 788. doi: 10.1016/j.jaci.2013.07.046

122. Kubo M. Mast cells and basophils in allergic inflammation. Curr Opin Immunol. (2018) 54:74-9. doi: 10.1016/j.coi.2018.06.006

123. Yamanishi Y, Miyake K, Iki M, Tsutsui H, Karasuyama H. Recent advances in understanding basophil-mediated Th2 immune responses. Immunol Rev. (2017) 278:237-45. doi: 10.1111/imr.12548

124. Ohnmacht C, Voehringer D. Basophil effector function and homeostasis during helminth infection. Blood. (2009) 113:281625. doi: 10.1182/blood-2008-05-154773

125. Wada $\mathrm{T}$, Ishiwata $\mathrm{K}$, Koseki $\mathrm{H}$, Ishikura $\mathrm{T}$, Ugajin $\mathrm{T}$, Ohnuma N, et al. Selective ablation of basophils in mice reveals their nonredundant role in acquired immunity against ticks. J Clin Invest. (2010) 120:286775. doi: 10.1172/JCI42680

126. Webb LM, Oyesola OO, Fruh SP, Kamynina E, Still KM, Patel RK, et al. The Notch signaling pathway promotes basophil responses during helminth-induced type 2 inflammation. J Exp Med. (2019) 216:126879. doi: 10.1084/jem.20180131

127. de Paulis A, Prevete N, Fiorentino I, Walls AF, Curto M, Petraroli A, et al. Basophils infiltrate human gastric mucosa at sites of Helicobacter pylori infection, and exhibit chemotaxis in response to $\mathrm{H}$. pylori-derived peptide $H p(2-20)$. J Immunol. (2004) 172:7734-43. doi: 10.4049/jimmunol.172.12.7734

128. de Paulis A, Prevete N, Rossi FW, Rivellese F, Salerno F, Delfino G, et al. Helicobacter pylori $\mathrm{Hp}(2-20)$ promotes migration and proliferation of gastric epithelial cells by interacting with formyl peptide receptors in vitro and accelerates gastric mucosal healing in vivo. J Immunol. (2009) 183:37619. doi: 10.4049/jimmunol.0900863

129. Guo CB, Liu MC, Galli SJ, Bochner BS, Kagey-Sobotka A, Lichtenstein LM. Identification of IgE-bearing cells in the late-phase response to antigen in the lung as basophils. Am J Respir Cell Mol Biol. (1994) 10:38490. doi: 10.1165/ajrcmb.10.4.7510984

130. Nouri-Aria KT, Irani AM, Jacobson MR, O’Brien F, Varga EM, Till SJ, et al. Basophil recruitment and IL-4 production during human allergen-induced late asthma. J Allergy Clin Immunol. (2001) 108:20511. doi: $10.1067 /$ mai.2001.117175

131. Ito Y, Satoh T, Takayama K, Miyagishi C, Walls AF, Yokozeki H. Basophil recruitment and activation in inflammatory skin diseases. Allergy. (2011) 66:1107-13. doi: 10.1111/j.1398-9995.2011.02570.x

132. DeNardo DG, Ruffell B. Macrophages as regulators of tumour immunity and immunotherapy. Nat Rev Immunol. (2019) 19:369-82. doi: 10.1038/s41577-019-0127-6

133. Mantovani A, Marchesi F, Malesci A, Laghi L, Allavena P. Tumour-associated macrophages as treatment targets in oncology. Nat Rev Clin Oncol. (2017) 14:399-416. doi: 10.1038/nrclinonc.2016.217

134. Marone G, Varricchi G, Loffredo S, Granata F. Mast cells and basophils in inflammatory and tumor angiogenesis and lymphangiogenesis. Eur $J$ Pharmacol. (2016) 778:146-51. doi: 10.1016/j.ejphar.2015.03.088

135. Hanahan D, Weinberg RA. Hallmarks of cancer: the next generation. Cell. (2011) 144:646-74. doi: 10.1016/j.cell.2011.02.013

136. Varricchi G, Loffredo S, Galdiero MR, Marone G, Cristinziano L, Granata F, et al. Innate effector cells in angiogenesis and lymphangiogenesis. Curr Opin Immunol. (2018) 53:152-60. doi: 10.1016/j.coi.2018.05.002

137. Sammarco G, Varricchi G, Ferraro V, Ammendola M, De Fazio M, Altomare $\mathrm{DF}$, et al. Mast cells, angiogenesis and lymphangiogenesis in human gastric cancer. Int J Mol Sci. (2019) 20:2106. doi: 10.3390/ijms20092106

138. Varricchi G, Loffredo S, Borriello F, Pecoraro A, Rivellese F, Genovese A, et al. Superantigenic activation of human cardiac mast cells. Int J Mol Sci. (2019) 20:1828. doi: 10.3390/ijms20081828

139. Detoraki A, Staiano RI, Granata F, Giannattasio G, Prevete N, de Paulis A, et al. Vascular endothelial growth factors synthesized by human lung mast cells exert angiogenic effects. J Allergy Clin Immunol. (2009) 123:11429. doi: 10.1016/j.jaci.2009.01.044

140. Granata F, Frattini A, Loffredo S, Staiano RI, Petraroli A, Ribatti D, et al. Production of vascular endothelial growth factors from human lung macrophages induced by group IIA and group $\mathrm{X}$ secreted phospholipases A2. J Immunol. (2010) 184:5232-41. doi: 10.4049/jimmunol.0902501

141. Loffredo S, Borriello F, Iannone R, Ferrara AL, Galdiero MR, Gigantino $\mathrm{V}$, et al. Group V secreted phospholipase A2 induces the release of proangiogenic and antiangiogenic factors by human neutrophils. Front Immunol. (2017) 8:443. doi: 10.3389/fimmu.2017.00443

142. Bilimoria J, Singh H. The Angiopoietin ligands and Tie receptors: potential diagnostic biomarkers of vascular disease. J Recept Signal Transduct Res. (2019) 39:187-93. doi: 10.1080/10799893.2019.1652650

143. Thomas M, Augustin HG. The role of the Angiopoietins in vascular morphogenesis. Angiogenesis. (2009) 12:12537. doi: 10.1007/s10456-009-9147-3

144. Leligdowicz A, Richard-Greenblatt M, Wright J, Crowley VM, Kain KC. Endothelial activation: the Ang/Tie axis in sepsis. Front Immunol. (2018) 9:838. doi: 10.3389/fimmu.2018.00838 
145. Jiang WG, Martin TA, Parr C, Davies G, Matsumoto K, Nakamura T. Hepatocyte growth factor, its receptor, and their potential value in cancer therapies. Crit Rev Oncol Hematol. (2005) 53:35-69. doi: 10.1016/j.critrevonc.2004.09.004

146. Kanaoka Y, Austen KF. Roles of cysteinyl leukotrienes and their receptors in immune cell-related functions. Adv Immunol. (2019) 142:6584. doi: 10.1016/bs.ai.2019.04.002

147. Colazzo F, Gelosa P, Tremoli E, Sironi L, Castiglioni L. Role of the cysteinyl leukotrienes in the pathogenesis and progression of cardiovascular diseases. Mediators Inflamm. (2017) 2017:2432958. doi: 10.1155/2017/2432958

148. Bankova LG, Dwyer DF, Yoshimoto E, Ualiyeva S, McGinty JW, Raff H, et al. The cysteinyl leukotriene 3 receptor regulates expansion of IL-25producing airway brush cells leading to type 2 inflammation. Sci Immunol. (2018) 3:eaat9453. doi: 10.1126/sciimmunol.aat9453

149. Bankova LG, Lai J, Yoshimoto E, Boyce JA, Austen KF, Kanaoka Y, et al. Leukotriene E4 elicits respiratory epithelial cell mucin release through the Gprotein-coupled receptor, GPR99. Proc Natl Acad Sci USA. (2016) 113:62427. doi: 10.1073/pnas.1605957113

150. Barrett NA, Fernandez JM, Maekawa A, Xing W, Li L, Parsons MW, et al. Cysteinyl leukotriene 2 receptor on dendritic cells negatively regulates ligand-dependent allergic pulmonary inflammation. J Immunol. (2012) 189:4556-65. doi: 10.4049/jimmunol.1201865

151. Duah E, Teegala LR, Kondeti V, Adapala RK, Keshamouni VG, Kanaoka Y, et al. Cysteinyl leukotriene 2 receptor promotes endothelial permeability, tumor angiogenesis, and metastasis. Proc Natl Acad Sci USA. (2019) 116:199204. doi: 10.1073/pnas.1817325115

152. Gevaert E, Zhang N, Krysko O, Lan F, Holtappels G, De Ruyck N, et al. Extracellular eosinophilic traps in association with Staphylococcus aureus at the site of epithelial barrier defects in patients with severe airway inflammation. J Allergy Clin Immunol. (2017) 139:1849-60 e1846. doi: 10.1016/j.jaci.2017.01.019

153. Papayannopoulos V. Neutrophil extracellular traps in immunity and disease. Nat Rev Immunol. (2018) 18:134-47. doi: 10.1038/nri.2017.105

154. Yousefi S, Gold JA, Andina N, Lee JJ, Kelly AM, Kozlowski E, et al. Catapultlike release of mitochondrial DNA by eosinophils contributes to antibacterial defense. Nat Med. (2008) 14:949-53. doi: 10.1038/nm.1855

155. Yousefi S, Simon D, Stojkov D, Karsonova A, Karaulov A, Simon HU. In vivo evidence for extracellular DNA trap formation. Cell Death Dis. (2020) 11:300. doi: 10.1038/s41419-020-2497-X

156. Brinkmann V, Reichard U, Goosmann C, Fauler B, Uhlemann Y, Weiss DS, et al. Neutrophil extracellular traps kill bacteria. Science. (2004) 303:15325. doi: $10.1126 /$ science. 1092385

157. Jaillon S, Peri G, Delneste Y, Fremaux I, Doni A, Moalli F, et al. The humoral pattern recognition receptor PTX3 is stored in neutrophil granules and localizes in extracellular traps. J Exp Med. (2007) 204:793804. doi: 10.1084/jem.20061301

158. Pilsczek FH, Salina D, Poon KK, Fahey C, Yipp BG, Sibley CD, et al. A novel mechanism of rapid nuclear neutrophil extracellular trap formation in response to Staphylococcus aureus. J Immunol. (2010) 185:741325. doi: 10.4049/jimmunol.1000675

159. Yipp BG, Petri B, Salina D, Jenne CN, Scott BN, Zbytnuik LD, et al. Infectioninduced NETosis is a dynamic process involving neutrophil multitasking in vivo. Nat Med. (2012) 18:1386-93. doi: 10.1038/nm.2847

160. Jorch SK, Kubes P. An emerging role for neutrophil extracellular traps in noninfectious disease. Nat Med. (2017) 23:279-87. doi: 10.1038/nm.4294

161. Cools-Lartigue J, Spicer J, McDonald B, Gowing S, Chow S, Giannias B, et al. Neutrophil extracellular traps sequester circulating tumor cells and promote metastasis. J Clin Invest. (2013) 72: 2972. doi: 10.1158/1538-7445.AM2012-2972

162. Park J, Wysocki RW, Amoozgar Z, Maiorino L, Fein MR, Jorns J, et al. Cancer cells induce metastasis-supporting neutrophil extracellular DNA traps. Sci Transl Med. (2016) 8:361ra138. doi: 10.1126/scitranslmed.aag1711

163. Teijeira A, Garasa S, Gato M, Alfaro C, Migueliz I, Cirella A, et al. CXCR1 and CXCR2 chemokine receptor agonists produced by tumors induce neutrophil extracellular traps that interfere with immune cytotoxicity. Immunity. (2020) 52:856-71 e858. doi: 10.1016/j.immuni.202 0.03 .001
164. Yang L, Liu Q, Zhang X, Liu X, Zhou B, Chen J, et al. DNA of neutrophil extracellular traps promotes cancer metastasis via CCDC25. Nature. (2020) 583:133-8. doi: 10.1038/s41586-020-2394-6

165. Albrengues J, Shields MA, Ng D, Park CG, Ambrico A, Poindexter $\mathrm{ME}$, et al. Neutrophil extracellular traps produced during inflammation awaken dormant cancer cells in mice. Science. (2018) 361:eaao4227. doi: 10.1126/science.aao4227

166. Wolach O, Sellar RS, Martinod K, Cherpokova D, McConkey M, Chappell $\mathrm{RJ}$, et al. Increased neutrophil extracellular trap formation promotes thrombosis in myeloproliferative neoplasms. Sci Transl Med. (2018) 10:eaan8292. doi: 10.1126/scitranslmed.aan8292

167. Cristinziano L, Modestino L, Loffredo S, Varricchi G, Braile M, Ferrara AL, et al. Anaplastic thyroid cancer cells induce the release of mitochondrial extracellular DNA traps by viable neutrophils. J Immunol. (2020) 204:136272. doi: 10.4049/jimmunol.1900543

168. Obata K, Mukai K, Tsujimura Y, Ishiwata K, Kawano Y, Minegishi Y, et al. Basophils are essential initiators of a novel type of chronic allergic inflammation. Blood. (2007) 110:913-20. doi: 10.1182/blood-2007-01-068718

169. Kojima T, Obata K, Mukai K, Sato S, Takai T, Minegishi Y, et al. Mast cells and basophils are selectively activated in vitro and in vivo through CD200R3 in an IgE-independent manner. J Immunol. (2007) 179:7093100. doi: 10.4049/jimmunol.179.10.7093

170. Hammad H, Plantinga M, Deswarte K, Pouliot P, Willart MA, Kool M, et al. Inflammatory dendritic cells-not basophils-are necessary and sufficient for induction of Th2 immunity to inhaled house dust mite allergen. J Exp Med. (2010) 207:2097-111. doi: 10.1084/jem.20101563

171. Hubner MP, Larson D, Torrero MN, Mueller E, Shi Y, Killoran KE, et al. Anti-FcepsilonR1 antibody injections activate basophils and mast cells and delay Type 1 diabetes onset in NOD mice. Clin Immunol. (2011) 141:20517. doi: 10.1016/j.clim.2011.08.004

172. Yoshimoto T, Yasuda K, Tanaka H, Nakahira M, Imai Y, Fujimori Y, et al. Basophils contribute to $\mathrm{T}(\mathrm{H}) 2-\mathrm{IgE}$ responses in vivo via IL-4 production and presentation of peptide-MHC class II complexes to CD4+ T cells. Nat Immunol. (2009) 10:706-12. doi: 10.1038/ni.1737

173. Perrigoue JG, Saenz SA, Siracusa MC, Allenspach EJ, Taylor BC, Giacomin $\mathrm{PR}$, et al. MHC class II-dependent basophil-CD4+ $\mathrm{T}$ cell interactions promote $\mathrm{T}(\mathrm{H}) 2$ cytokine-dependent immunity. Nat Immunol. (2009) 10:697-705. doi: 10.1038/ni.1740

174. Sawaguchi M, Tanaka S, Nakatani Y, Harada Y, Mukai K, Matsunaga $\mathrm{Y}$, et al. Role of mast cells and basophils in IgE responses and in allergic airway hyperresponsiveness. J Immunol. (2012) 188:180918. doi: 10.4049/jimmunol.1101746

175. Ugajin T, Kojima T, Mukai K, Obata K, Kawano Y, Minegishi Y, et al. Basophils preferentially express mouse mast cell protease 11 among the mast cell tryptase family in contrast to mast cells. J Leukoc Biol. (2009) 86:1417-25. doi: 10.1189/jlb.0609400

176. Poorafshar M, Helmby H, Troye-Blomberg M, Hellman L. MMCP8, the first lineage-specific differentiation marker for mouse basophils. Elevated numbers of potent IL-4-producing and MMCP-8-positive cells in spleens of malaria-infected mice. Eur J Immunol. (2000) 30:2660 8. doi: 10.1002/1521-4141(200009)30:9<2660::AID-IMMU2660>3.0.CO;2I.

177. El Hachem C, Hener P, Kirstetter P, Li J, Chan S, Li M. Treatment of MCPT8(DTR) mice with high- or low-dose diphtheria toxin leads to differential depletion of basophils and granulocyte-macrophage progenitors. Eur J Immunol. (2018) 48:861-73. doi: 10.1002/eji.201747351

178. Sullivan BM, Liang HE, Bando JK, Wu D, Cheng LE, McKerrow JK, et al. Genetic analysis of basophil function in vivo. Nat Immunol. (2011) 12:52735. doi: 10.1038/ni.2036

179. Ohnmacht C, Schwartz C, Panzer M, Schiedewitz I, Naumann R, Voehringer D. Basophils orchestrate chronic allergic dermatitis and protective immunity against helminths. Immunity. (2010) 33:364-74. doi: 10.1016/j.immuni.2010.08.011

180. Mukai K, BenBarak MJ, Tachibana M, Nishida K, Karasuyama H, Taniuchi I, et al. Critical role of P1-Runx1 in mouse basophil development. Blood. (2012) 120:76-85. doi: 10.1182/blood-2011-12-399113 
181. Karasuyama H, Obata K, Wada T, Tsujimura Y, Mukai K. Newly appreciated roles for basophils in allergy and protective immunity. Allergy. (2011) 66:1133-41. doi: 10.1111/j.1398-9995.2011.02613.x

182. Schwartz C, Eberle JU, Voehringer D. Basophils in inflammation. Eur J Pharmacol. (2016) 778:90-5. doi: 10.1016/j.ejphar.2015.04.049

183. Denburg JA, Browman G. Prognostic implications of basophil differentiation in chronic myeloid leukemia. Am J Hematol. (1988) 27:110-4. doi: 10.1002/ajh.2830270208

184. Beer PA, Knapp DJ, Miller PH, Kannan N, Sloma I, Heel K, et al. Disruption of IKAROS activity in primitive chronic-phase CML cells mimics myeloid disease progression. Blood. (2015) 125:504-15. doi: 10.1182/blood-2014-06-581173

185. Baba T, Naka K, Morishita S, Komatsu N, Hirao A, Mukaida N. MIPlalpha/CCL3-mediated maintenance of leukemia-initiating cells in the initiation process of chronic myeloid leukemia. J Exp Med. (2013) 210:266173. doi: $10.1084 /$ jem. 20130112

186. Baba T, Tanabe Y, Yoshikawa S, Yamanishi Y, Morishita S, Komatsu N, et al. MIP-1alpha/CCL3-expressing basophil-lineage cells drive the leukemic hematopoiesis of chronic myeloid leukemia in mice. Blood. (2016) 127:260717. doi: 10.1182/blood-2015-10-673087

187. Matsushima T, Handa H, Yokohama A, Nagasaki J, Koiso H, Kin Y, et al. Prevalence and clinical characteristics of myelodysplastic syndrome with bone marrow eosinophilia or basophilia. Blood. (2003) 101:338690. doi: 10.1182/blood-2002-03-0947

188. Wimazal F, Germing U, Kundi M, Noesslinger T, Blum S, Geissler P, et al. Evaluation of the prognostic significance of eosinophilia and basophilia in a larger cohort of patients with myelodysplastic syndromes. Cancer. (2010) 116:2372-81. doi: $10.1002 / \mathrm{cncr} .25036$

189. Varricchi G, Ameri P, Cadeddu C, Ghigo A, Madonna R, Marone G, et al. Antineoplastic Drug-Induced Cardiotoxicity: A Redox Perspective. Front Physiol. (2018) 9:167. doi: 10.3389/fphys.2018.00167

190. Wei Y, Zhang X, Wang G, Zhou Y, Luo M, Wang S, et al. The impacts of pretreatment circulating eosinophils and basophils on prognosis of stage - colorectal cancer. Asia Pac J Clin Oncol. (2018) 14:e243e251. doi: 10.1111/ajco.12871

191. Liu Q, Luo D, Cai S, Li Q, Li X. Circulating basophil count as a prognostic marker of tumor aggressiveness and survival outcomes in colorectal cancer. Clin Transl Med. (2020) 9:6. doi: 10.1186/s40169-019-0255-4

192. Cihan YB, Arslan A, Cetindag MF, Mutlu H. Lack of prognostic value of blood parameters in patients receiving adjuvant radiotherapy for breast cancer. Asian Pac J Cancer Prev. (2014) 15:4225-31. doi: 10.7314/APJCP.2014.15.10.4225

193. Grimm M, Rieth J, Hoefert S, Krimmel M, Rieth S, Teriete P, et al. Standardized pretreatment inflammatory laboratory markers and calculated ratios in patients with oral squamous cell carcinoma. Eur Arch Otorhinolaryngol. (2016) 273:3371-84. doi: 10.1007/s00405-016-3950-4

194. Rosner S, Kwong E, Shoushtari AN, Friedman CF, Betof AS, Brady MS, et al. Peripheral blood clinical laboratory variables associated with outcomes following combination nivolumab and ipilimumab immunotherapy in melanoma. Cancer Med. (2018) 7:690-7. doi: 10.1002/cam4.1356

195. Ferro M, Di Lorenzo G, Vartolomei MD, Bruzzese D, Cantiello F, Lucarelli G, et al. Absolute basophil count is associated with time to recurrence in patients with high-grade T1 bladder cancer receiving bacillus CalmetteGuerin after transurethral resection of the bladder tumor. World J Urol. (2020) 38:143-50. doi: 10.1007/s00345-019-02754-2

196. Wang C, Chen YG, Gao JL, Lyu GY, Su J, Zhang QI, et al. Low local blood perfusion, high white blood cell and high platelet count are associated with primary tumor growth and lung metastasis in a $4 \mathrm{~T} 1$ mouse breast cancer metastasis model. Oncol Lett. (2015) 10:754-60. doi: 10.3892/ol.2015.3304

197. Spivak JL. How I treat polycythemia vera. Blood. (2019) 134:34152. doi: 10.1182/blood.2018834044

198. Vannucchi AM, Antonioli E, Guglielmelli P, Rambaldi A, Barosi G, Marchioli $\mathrm{R}$, et al. Clinical profile of homozygous JAK2 $617 \mathrm{~V}>\mathrm{F}$ mutation in patients with polycythemia vera or essential thrombocythemia. Blood. (2007) 110:840-6. doi: 10.1182/blood-2006-12-064287

199. Tefferi A, Barbui T. Polycythemia vera and essential thrombocythemia: 2019 update on diagnosis, risk-stratification and management. Am J Hematol. (2019) 94:133-43. doi: 10.1002/ajh.25303
200. Tefferi A, Lavu S, Mudireddy M, Lasho TL, Finke CM, Gangat N, et al. JAK2 exon 12 mutated polycythemia vera: Mayo-Careggi MPN Alliance study of 33 consecutive cases and comparison with JAK2V617F mutated disease. Am J Hematol. (2018) 93:E93-6. doi: 10.1002/ajh.25017

201. Ishii T, Wang J, Zhang W, Mascarenhas J, Hoffman R, Dai Y, et al. Pivotal role of mast cells in pruritogenesis in patients with myeloproliferative disorders. Blood. (2009) 113:5942-50. doi: 10.1182/blood-2008-09-179416

202. Hashimoto T, Rosen JD, Sanders KM, Yosipovitch G. Possible roles of basophils in chronic itch. Exp Dermatol. (2019) 28:1373-9. doi: 10.1111/exd.13705

203. Pieri L, Bogani C, Guglielmelli P, Zingariello M, Rana RA, Bartalucci $\mathrm{N}$, et al. The JAK2V617 mutation induces constitutive activation and agonist hypersensitivity in basophils from patients with polycythemia vera. Haematologica. (2009) 94:1537-45. doi: 10.3324/haematol.2009.007047

204. Bax HJ, Chauhan J, Stavraka C, Khiabany A, Nakamura M, Pellizzari G, et al. Basophils from cancer patients respond to immune stimuli and predict clinical outcome. Cells. (2020) 9:1631. doi: 10.3390/cells9071631

205. Zilionis R, Engblom C, Pfirschke C, Savova V, Zemmour D, Saatcioglu HD, et al. Single-cell transcriptomics of human and mouse lung cancers reveals conserved myeloid populations across individuals and species. Immunity. (2019) 50:1317-34 e1310. doi: 10.1016/j.immuni.2019.03.009

206. Schroeder JT, Adeosun AA, Do D, Bieneman AP. Galectin-3 is essential for IgE-dependent activation of human basophils by A549 lung epithelial cells. $J$ Allergy Clin Immunol. (2019) 144:312-5 e311. doi: 10.1016/j.jaci.2019.03.001

207. Sciacchitano S, Lavra L, Morgante A, Ulivieri A, Magi F, De Francesco GP, et al. Galectin-3: one molecule for an alphabet of diseases, from A to Z. Int $J$ Mol Sci. (2018) 19:379. doi: 10.3390/ijms19020379

208. Lucarini V, Ziccheddu G, Macchia I, La Sorsa V, Peschiaroli F, Buccione $\mathrm{C}$, et al. IL-33 restricts tumor growth and inhibits pulmonary metastasis in melanoma-bearing mice through eosinophils. Oncoimmunology. (2017) 6:e1317420. doi: 10.1080/2162402X.2017.1317420

209. Andreone S, Spadaro F, Buccione C, Mancini J, Tinari A, Sestili P, et al. IL33 Promotes CD11b/CD18-mediated adhesion of eosinophils to cancer cells and synapse-polarized degranulation leading to tumor cell killing. Cancers. (2019) 11:1664. doi: 10.3390/cancers11111664

210. De Monte L, Reni M, Tassi E, Clavenna D, Papa I, Recalde H, et al. Intratumor T helper type 2 cell infiltrate correlates with cancer-associated fibroblast thymic stromal lymphopoietin production and reduced survival in pancreatic cancer. J Exp Med. (2011) 208:469-78. doi: 10.1084/jem.20101876

211. Borriello F, Longo M, Spinelli R, Pecoraro A, Granata F, Staiano RI, et al. IL-3 synergises with basophil-derived IL- 4 and IL-13 to promote the alternative activation of human monocytes. Eur J Immunol. (2015) 45:204251. doi: $10.1002 /$ eji.201445303

212. Sakaguchi S, Yamaguchi T, Nomura T, Ono M. Regulatory $\mathrm{T}$ cells and immune tolerance. Cell. (2008) 133:775-87. doi: 10.1016/j.cell.2008.05.009

213. Najafi M, Farhood B, Mortezaee K. Contribution of regulatory $\mathrm{T}$ cells to cancer: a review. J Cell Physiol. (2019) 234:7983-93. doi: 10.1002/jcp.27553

214. Jorgensen N, Persson G, Hviid TVF. The tolerogenic function of regulatory $\mathrm{T}$ cells in pregnancy and cancer. Front Immunol. (2019) 10:911. doi: 10.3389/fimmu.2019.00911

215. Das M, Stephen-Victor E, Bayry J. Regulatory T cells do not suppress rather activate human basophils by IL-3 and STAT5-dependent mechanisms. Oncoimmunology. (2020) 9:1-3. doi: 10.1080/2162402X.2020.1773193

216. Vernersson M, Aveskogh M, Hellman L. Cloning of IgE from the echidna (Tachyglossus aculeatus) and a comparative analysis of epsilon chains from all three extant mammalian lineages. Dev Comp Immunol. (2004) 28:6175. doi: 10.1016/S0145-305X(03)00084-3

217. Harris N, Gause WC. To B or not to B: B cells and the Th2type immune response to helminths. Trends Immunol. (2011) 32:808. doi: $10.1016 /$ j.it.2010.11.005

218. Marichal T, Starkl P, Reber LL, Kalesnikoff J, Oettgen HC, Tsai M, et al. A beneficial role for immunoglobulin $\mathrm{E}$ in host defense against honeybee venom. Immunity. (2013) 39:963-75. doi: 10.1016/j.immuni.201 3.10 .005

219. Palm NW, Rosenstein RK, Yu S, Schenten DD, Florsheim E, Medzhitov $R$. Bee venom phospholipase A2 induces a primary type 2 response that is dependent on the receptor ST2 and confers protective immunity. Immunity. (2013) 39:976-85. doi: 10.1016/j.immuni.2013.10.006 
220. Starkl P, Marichal T, Gaudenzio N, Reber LL, Sibilano R, Tsai M, et al. IgE antibodies, FcepsilonRIalpha, and IgE-mediated local anaphylaxis can limit snake venom toxicity. J Allergy Clin Immunol. (2016) 137:246-57 e211. doi: 10.1016/j.jaci.2015.08.005

221. Zellweger F, Eggel A. IgE-associated allergic disorders: recent advances in etiology, diagnosis, and treatment. Allergy. (2016) 71:1652-61. doi: 10.1111/all.13059

222. Oettgen HC. Fifty years later: Emerging functions of IgE antibodies in host defense, immune regulation, and allergic diseases. J Allergy Clin Immunol. (2016) 137:1631-45. doi: 10.1016/j.jaci.2016.04.009

223. MacGlashan D Jr. IgE receptor and signal transduction in mast cells and basophils. Curr Opin Immunol. (2008) 20:71723. doi: 10.1016/j.coi.2008.08.004

224. Crawford G, Hayes MD, Seoane RC, Ward S, Dalessandri T, Lai C, et al. Epithelial damage and tissue gammadelta $\mathrm{T}$ cells promote a unique tumor-protective IgE response. Nat Immunol. (2018) 19:85970. doi: 10.1038/s41590-018-0161-8

225. Abel EL, Angel JM, Kiguchi K, DiGiovanni J. Multi-stage chemical carcinogenesis in mouse skin: fundamentals and applications. Nat Protoc. (2009) 4:1350-62. doi: 10.1038/nprot.20 09.120

226. Marone G. Basophils, historical reflections and perspectives. In: Bergman KC, Ring J, editors. History of Allergy. Basel: Karger (2014). p. 214.

227. Borriello F, Granata F, Varricchi G, Genovese A, Triggiani M, Marone G. Immunopharmacological modulation of mast cells. Curr Opin Pharmacol. (2014) 17:45-57. doi: 10.1016/j.coph.201 4.07.002
228. Visciano C, Liotti F, Prevete N, Cali G, Franco R, Collina F, et al. Mast cells induce epithelial-to-mesenchymal transition and stem cell features in human thyroid cancer cells through an IL-8-Akt-Slug pathway. Oncogene. (2015) 34:5175-86. doi: 10.1038/onc.2014.441

229. Phythian-Adams AT, Cook PC, Lundie RJ, Jones LH, Smith KA, Barr TA, et al. CD11c depletion severely disrupts Th2 induction and development in vivo. J Exp Med. (2010) 207:2089-96. doi: 10.1084/jem.20100734

230. Tang H, Cao W, Kasturi SP, Ravindran R, Nakaya HI, Kundu K, et al. The $\mathrm{T}$ helper type 2 response to cysteine proteases requires dendritic cellbasophil cooperation via ROS-mediated signaling. Nat Immunol. (2010) 11:608-17. doi: 10.1038/ni.1883

Conflict of Interest: The authors declare that the research was conducted in the absence of any commercial or financial relationships that could be construed as a potential conflict of interest.

Citation: Marone G, Schroeder JT, Mattei F, Loffredo S, Gambardella AR, Poto R, de Paulis A, Schiavoni $G$ and Varricchi $G$ (2020) Is There a Role for Basophils in Cancer? Front. Immunol. 11:2103. doi: 10.3389/fimmu.2020.02103

Copyright (c) 2020 Marone, Schroeder, Mattei, Loffredo, Gambardella, Poto, de Paulis, Schiavoni and Varricchi. This is an open-access article distributed under the terms of the Creative Commons Attribution License (CC BY). The use, distribution or reproduction in other forums is permitted, provided the original author(s) and the copyright owner(s) are credited and that the original publication in this journal is cited, in accordance with accepted academic practice. No use, distribution or reproduction is permitted which does not comply with these terms. 